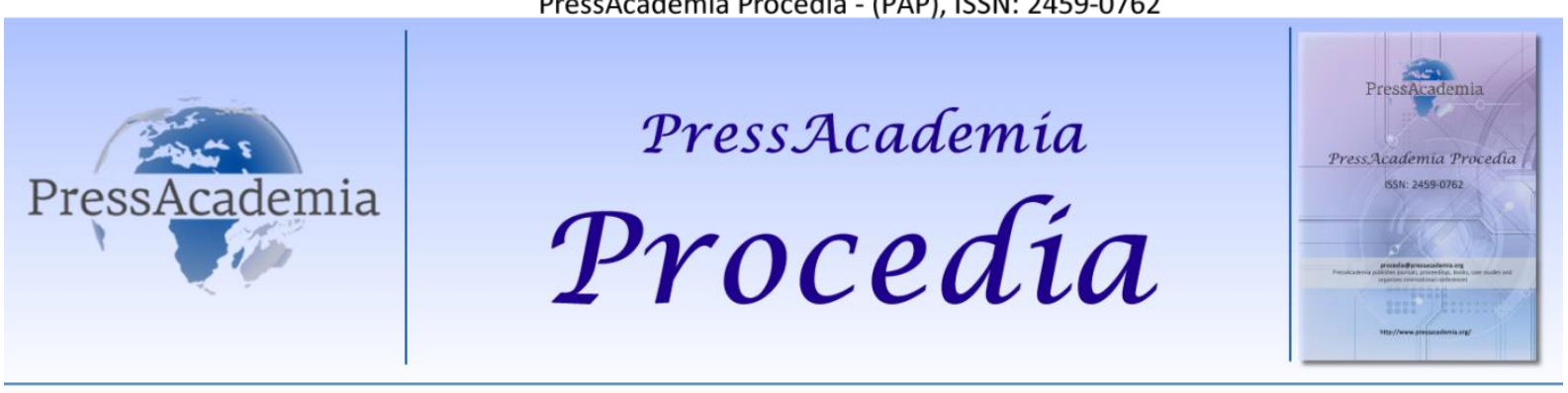

Global Business Research Congress (GBRC), May 24-25, 2017, Istanbul, Turkey

\title{
THE EFFECT OF BRAND LOYALTY OF INVOLVEMENT TO PRODUCTS: THE SAMPLE OF MOBILE PHONE
}

\section{DOI: 10.17261/Pressacademia.2017.641} PAP- GBRC-V.3-2017(67)-p.646-

\section{Ece Armağan ${ }^{1}$, Gökhan Akel ${ }^{2}$}

${ }^{1}$ Adnan Menderes University, Department of Business, Aydın, Turkey. ecearmagan@adu.edu.tr

${ }^{2}$ Antalya Akev University, Department of Business, Antalya, Turkey. g.akel@akev.edu.tr

\section{To cite this document}

Armagan, E. and G. Akel (2017). The effect of brand loyalty of involvement to products: the sample of mobile phone. PressAcademia Procedia (PAP), V.3, p.646-

Permemant link to this document: $h$ ttp://doi.org/10.17261/Pressacademia.2017.641

Copyright: Published by PressAcademia and limited licenced re-use rights only.

\begin{abstract}
Brands in a highly competitive environment is considered as the main assets of businesses, businesses that create brand loyalty ensures that there is a long period of time. In order to ensure brand loyalty also consumers' involvement need to be investigated. Brand loyalty is also a great benefit in understanding consumers' level of involvement on the brand. The product involvement required to understand consumer behavior is an important factor on brand loyalty. In this study, the effect of the involvement factors on the brand loyalty of the businesses used by the mobile phone users on the brand are examined. First, a literature search for the factors that influence brand loyalty, and each of these factors were discussed in detail. In the study, Kapferer and Laurent (1985)'s Consumer Involvement Profile Scale (CIP) has emerged. T-test, Anova and regression analysis, were used to test hypotheses. The sub-factors of consumer involvement are interest and pleasure, sign value, risk importance, risk probability, awareness of the product's origin, product knowledge and awareness of product attributes. Differences between the socio-demographic characteristics of the consumer and these sub-dimensions have been identified. As a result of the study, it has been determined that the "interest and pleasure", "sign value", "risk importance", "product knowledge" and "awareness of product attributes" factors of the mobile phone users' involvement factors are related to brand loyalty.
\end{abstract}

Keywords : Involvement, brand loyalty, consumer behavior, consumer involvement profile scale, mobile phone JEL Codes: M30, M31, L82

\section{ÜRÜNLERE OLAN ILGILENIMIN MARKA SADAKATi ÜZERINE ETKISi: CEP TELEFONU ÖRNEĞi}

\section{ÖZET}

Markalar işletmelerin ana varlıkları olarak kabul edildiğinden yüksek rekabet ortamında, marka sadakati yaratmak işletmelerin uzun dönemde var olmasını sağlamaktadır. Marka sadakati sağlamak için de tüketicilerin markaya olan ilgilenim düzeylerinin anlaşıımasında büyük yarar vardır. Tüketici davranışlarının anlaşılması için gerekli olan ürün ilgilenimi marka sadakati konusunda önemli bir faktördür. Bu çalışmada, cep telefonu kullanıcılarının kullandıkları markaya olan ilgilenim faktörlerinin işletmelerin marka sadakati üzerindeki etkisi incelenmiştir. Illk olarak, marka sadakatine etki eden faktörler için literatür araştırması yapılmış ve bu faktörlerin her biri detaylı bir şekilde ele alınmıştır. Çalışmada Kapferer ve Laurent'in (1985) Tüketici İlgilenimi Profili Ölçeği (CIP)'nden yola çıkılmıştır. Hipotezleri test etmek için t-testi, Anova ve regresyon analizi kullanılmıştır. Tüketici ilgileniminin alt faktörleri ilgi ve haz, sembolik değer, risk önemi, hata olasılığı, ürün menşei farkındalığı, ürün bilgisi ve ürün özellikleri bilinci olarak belirlenmiştir. Tüketicinin sosyo-demografik özellikleri ile bu alt boyutlar arasında farklııklar saptanmıştır. Çalışma sonucunda cep telefonu kullanıcıların ilgilenim faktörlerinden "ilgi ve haz", "sembolik değer", "risk önemi”, "ürün bilgisi” ve "ürün özellikleri bilinci” faktörlerinin marka sadakati üzerinde etkili olduğu belirlenmiştir.

Anahtar Kelimeler: İlgilenim, marka sadakati, tüketici davranışı, tüketici ilgilenimi profili ölçeği, cep telefonu JEL Kodları: M30, M31, L82 


\section{GiRiş}

İşletmeler arasındaki rekabetin ciddi bir savaşa dönüştüğü günümüzde başarılı bir markaya sahip olmak rekabet avantajı sağlama yolundaki en önemli unsurların biridir. Aaker (1991)'e göre markalar, işletmelere istikrar getirir, rekabet taklitçiliğine karşı koruma sağlar ve tüketicilerin giderek daha karmaşık dünyaya güvenle alışveriş etmelerini sağlar. Dahası, bu konuda başarılı olmuş bir işletmenin başarısının devamı için mevcut müşterileri koruması ve marka sadakatini pekiştirmesi gerekmektedir (Dekimpe vd., 1997). Marka sadakati sağlamak için de tüketicilerin markaya olan ilgilenim düzeylerinin anlaşılması gerekmektedir. İlgilenim kavramı, tüketici davranışını açıklamada giderek önemli bir rol oynamaktadır (Mittal ve Lee, 1989). Pazarlama ve tüketici araştırmaları kapsamında son yıllarda Türkiye'de de ilgilenim (involvement) kavramı büyük ilgi görmektedir. Bu kavram tüketici davranışları ve pazarlama yapıları ile bağlantılıdır. Ürünlerin sınıflandırılması ilgilenim düzeyine göre yapılmaktadır (Michaelidou ve Dibb, 2008). Tüketici davranışı konusunda araştırma yapan akademisyen ve araştırmacılar genellikle ortaya çıkan davranışları ilgilenim düzeyini belirlemek amacıyla kullanmaktadır (Zaichkowsky, 1985). Bu çalışma, ilgilenim konusundaki güncel literatürün özeti olmasının yanı sıra, ilgilenim kavramının literatürdeki yeri üzerinden hareketle, ilgilenimin faktörleri olarak kabul edilen ilgi, haz, sembolik değer, riskin önemi, hata olasılı̆̆ı, kendini ifade etme, ürün menşei farkındalığı, ürün bilgisi ve ürün özellikleri bilincinin marka sadakati üzerindeki etkisini incelemektedir.

\section{LITERATÜR INCELEMESI}

\subsection{Marka Sadakati}

Günümüzde, işletmelerin entelektüel sermayeleri içerisinde değerlendirilen marka, Amerikan Pazarlama Birliği (AMA, 2017) tarafından "adı, sembol, ya da tasarım ya da bunların bir kombinasyonu ile malların bir satıcı ya da satıcıların hizmetinde tanımlanmasını ve bunları rakiplerinden ayrılabilmeyi amaçlamaktadır" şeklinde tanımlanmıştır. Sadakat ise, Oliver (1997) tarafından gelecekte sürekli olarak tercih edilen bir ürünün veya hizmetin yeniden pazarlığa girilmesi ya da yeniden pazarlanması konusundaki kararlılı̆ı; Rundle-Thiele ve Mackay, (2001) tarafından da, "tüketicilerin markalara, hizmetlere, ürün kategorilerine, faaliyetlere ve mağazalara gösterebileceği bir konudur" şeklinde tanımlanmıştır.

Durumsal etkilerin ve pazarlama çabalarının tüketici davranışlarını değiştirme ihtimali olmasına rağmen, sadakat tüketiciyi aynı markaya karşı satın alma davranışına yönlendirmektedir (Oliver 1999). İnsan davranışlarını etkileyen en önemli unsurlardan biri olan duygusal bağ, tüketici davranışlarında da önemli bir faktördür. Morris vd., (2002), tüketicilerin ürün veya hizmetlere olan davranışsal niyetlerinin ve bu ürün veya hizmetlerle mevcut bir ilişkiye devam etmenin duygulardan çok önemli ölçüde etkilendiğini belirtmiştir.

Bugünün iş dünyasında oldukça önemli bir konu olan marka sadakatini Jacoby and Kyner (1973), Biong (1993) ve RundleThiele and Mackay (2001), "belirli bir markadan memnun kalan tüketicilerin tekrarlayan satın alma davranışı veya sürekli olarak tercih edilen bir ürün/hizmetin markasını gelecekte de tekrar tercih etme eğilimi" olarak ifade etmişlerdir. Dolayısıyla belli bir markaya sadakati olan bir tüketicinin, bu marka ürünü tekrar kullanması beklenmektedir. Marka sadakati aynı zamanda karar alma sürecinin bir sonucudur ve aynı markayı satın almaya devam etmek için bilinçli bir kararı yansıtan bir tekrar alım davranışı şeklidir (Nguyen, 2013).

Quester ve Lim (2003), belirli bir markayla daha fazla ilgilenen tüketicilerin o markaya daha fazla bağlı olduğunu ve dolayısıyla sadakat duygusunun daha güçlü olduğunu, ayrıca, ürün ilgileniminin marka sadakatini etkileyen etkileyen faktörler arasında en yüksek ağırlığa sahip olduğunu ifade etmiştir.

\section{2. İlgilenim ve İIgilenim Düzeyleri}

Literatürde farkı bilim dallarının yanı sıra, pazarlama ve tüketici araştırmacıları tarafından da farklı perspektiften tanımlamalarının olması, ilgilenim kavramının evrensel bir tanımının olmamasına sebep olmuştur. ilgilenim kavramı çeşitli şekillerde tanımlanmış olup, bunlardan bazıları aşă̆ıdaki gibidir.

Tüketici davranışlarını açıklamada önemli bir kavram olan ilgilenim, tüketicilerin karar verme sürecini ve iletişim davranışlarını etkileyen bireysel bir farklılık değişkenidir (Michaelidou ve Dibb, 2008).

Zaichkowsky (1985) tarafından yapılan tanıma göre ilgilenim, "kişinin ihtiyaçları, değer yargıları ve ilgi alanlarına bağı olarak herhangi bir ürüne karşı algıladığı yakınlık ve ilgidir". Farklı bir perspektiften ilgilenim kavramını tanımlayan Morris vd., (2002); kişinin herhangi bir uyarana karşı duyduğu psikolojik ve duygusal bağın yoğunluğu olarak konuya açıklık getirmiştir.

İlgilenim, tüketicilerin bilişsel ve duyuşsal süreçlerini ve davranışlarını karar verdikçe güçlendiren ve yönlendiren motive edici bir durumdur. Tüketiciler hangi markayı tercih edeceği konusunda motive oldukları söylenebilir. Mağazaları gezerek, 
internet ortamında araştırma yaparak herhangi bir ürün için daha fazla zaman ve çaba gösterebilir. Reklamları takip ederek ve dergileri okuyarak çevreden bilgi elde etmeye çalışabilir. Ayrıca, daha fazla zaman ve çaba harcayarak ürün hakkında bilgileri bütünleştirebilir ve alternatif markaları değerlendirerek satın alma seçimi yapabilir (Nguyen, 2013).

Bu tanımlara ek olarak Laurent ve Kapferer (1985) ilgilenim kavramını aşağıdaki gibi farklı faktörlerin etkisi altında olduğunu ifade etmişitir:

- Ürüne karşı duyulan ilgi,

- Ürüne karşı duyulan haz,

- Ürünün satın alınması ve tüketilmesinin sembolik değeri

- Ürünün satın alınması ile ilgili risk,

Laurent ve Kapferer (1985) tüketicilerin ürünlere ilgilenimini uygulanabilir hale getirmek için Tüketici ilgilenim Profilini geliştirmiştir.

Son yıllarda tüketici araştırmalarına odaklanmanın bir sonucu olarak çok önemli bir değişken haline gelen ilgilenim, Kim (2005)'e göre, tüketicilerin ürün kategorisiyle olan ilgilenim seviyesinin, ürün hakkında karar vermeyi ve ürün bilgisi araştırmalarını etkilediğini belirtmiştir.

Traylor (1981) ilgilenim kavramını, belirli bir ürünün tüketici tarafından anlaşılması veya tanınması olarak tanımlamaktadır. Ürünün tüketici tarafından göz önüne alındığında yüksek seviyede ilgilenime yüksek ilgilenim, daha düşük seviyede ilgilenime ise düşük ilgilenim denmektedir.

\subsubsection{Yüksek İlgilenim}

Antil (1984)'e göre kişilik farklııkları, önceki tecrübeler, tüketicinin sosyo-demografik durumu gibi faktörler nedeniyle farklı kişilerin aynı konu üzerinde ilgilenim düzeyleri değişiklik göstermektedir.

Tüketicinin yüksek ilgilenimli olması durumunda kişi belirli bir probleme daha fazla dikkat ve çaba sarfetmektedir (Xue, 2008). Tüketicinin yüksek ilgilenimli olması satın alma kararı vermede daha fazla zaman ve çaba harcamaya istekli olmasına sebep olmaktadır (Suh ve Youjae, 2006). Bu tanımlardan yola çıkarak, tüketici yüksek ilgilenimli olma durumlarında ürün hakkında oldukça fazla bilgi elde eder, bilgileri inceler ve üzerine uzun süre düşündükten sonra satın alma kararı verir.

Yüksek ilgilenimli satın alımlarda, algılanan risk açısından tüketiciler için çok önemli olan alımlardır ve tüketicilerin kapsamlı bir problem çözme girişiminde bulunmalarını ister. Tüketicilerin bir ürün kategorisini veya o kategorideki belirli markaları değerlendirmek için belirlenmiş kriterleri olmadığında, karar çabaları kapsamlı bir problem çözme olarak adlandırılabilir (Nguyen, 2013).

Yüksek ilgilenimli ürünlerin yüksek risk barındıran ve nadiren satın alınıp değer katan ürünler olduğu söylenebilir. Söz konusu olan risk finansal risk olarak dikkate alınmalıdır. Parfüm, kıyafet veya mücevher gibi yüksek ilgilenimli ürünlerin seçimi sosyal risk olarak adlandırılırlar. Tüketici, mümkün olduğu kadar riski azaltmak amacıyla satın alma kararını vermeden önce, ürün arşivinde veya menşe ülkesinde bilgi ararken çok fazla zaman ve çaba harcamaktadır (Nguyen, 2013).

\subsubsection{Düşük ilgilenim}

Düşük ilgilenimli karar süreci, ilgilenim düzeyinin, bilişsel çaba miktarının ve bilgi arama sürecinin azalması varsayımı ile ifade edilmektedir. Nispeten önemsiz olan düşük ilgilenimli karar süreçlerinde amaç, seçimi optimize etmek değil, bilişsel çabayı minimize ederken tatmin edici bir seçim yapmak olduğu düşünülmektedir (Elliott, ve Hamilton, 1991).

Richins ve Bloch (1986)'a göre ise, yüksek ilgilenimli tüketicilerin ürünleri ilginç bulacaklarını, bu nedenle, anında satın alma uyarısı olmaksızın tüketicilerin düşüncelerini işgal edeceğini belirtmiştir. Dolayısıyla, yüksek ilgilenimli alımlar tüketici için önemli ve ilgi çekicidir ve alternatifler arasında çok fazla bilgi aramaya neden olmaktadır; düşük ilgilenimli alımlarda ise tüketici için çok bir önemi yoktur ve çok fazla ilgisini çekmez, bu nedenle alım gerçekleştirmeden önce bilgi aramaya çok az veya hiç zaman ayırmazlar (Josiam vd., 2005).

Richins ve Bloch (1986), tüketicilerin yüksek ilgilenimli ürünlere hızlı bir satın alma kararı vermediğini belirtmiştir. Düşük ilgilenimli ürünler ise daha az ilgi gördüğü gibi daha az risklidir. Bu nedenle satın alma sürecinde daha az bilgi ve çaba gerektirir. Örneğin, bir araba satın almak kalem satın almaktan tamamen farklıdır, çünkü araç yüksek değerdedir ve alıcının satın alma işlemini gerçekleştirmeden önce dikkatli bir şekilde düşünmesi gerekmektedir, alıcının yanlış bir karar vermesi durumunda oluşabilecek bazı potansiyel riskler barındırmaktadır. Kalem ise düşük değerdedir ve alıcının çok dikkatli bir şekilde düşünmesini gerektirmediği gibi herhangi bir risk barındırmaz (Nguyen, 2013). 
Düşük ilgilenim, bir ürün satın alımı ile ilgili zihinsel ilgilenimin düşük olduğu anlamına gelir. Yıkama bezi, diş macunu, tahıllar gibi düşük fiyatlı ürünler için bilgi toplamak ve çaba harcamak gerekmemektedir. Alkollü ve alkolsüz içecekler, her türlü sigara ve çikolata gibi ürünler de düşük ilgilenimli ürünler arasındadır (Nguyen, 2013).

\subsection{Tüketici Ilgilenimi Profili ve Boyutları}

İlgilenim kavramı çok boyutlu bir yapı olarak incelenilmesi gerektiği için, sadece tek bir boyut kavramın açıklamasında yetersiz olarak görünmektedir. Ayrıca, tüketicilerin tüketim davranışlarını ve marka tercihlerini anlamak için, tüketici davranışının arkasındaki nedenlerin araştırılması gerekmektedir. Marka sadakatine etki edebilecek ilgilenim faktörleri, derinlemesine literatür taraması akabinde derlenmiş ve bu çalışmaya entegre edilmiştir. Marka sadakatine etkisi incelenen ilgilenim boyutları; ürün bilgisi, sembolik değer, ürün menşei farkındalığı, hedonik değer, ilgi, hata olasılığı ve risk olarak belirlenmiştir.

Müşterinin sahip olduğu genel bilgi olarak tanımlanan ürün bilgisi, tüketici davranışı araştırmalarında önemli bir rol oynamaktadır. Bu nedenle ilgili alanlarda önemli bir araştırma konusudur (Lin ve Chen, 2006). Satın alma gerçekleşirken önemli bir unsur olan ürün bilgisi, ürüne olan aşinalık, uzmanlık ve deneyim gibi çeşitli isimler altında incelenmiştir (Lee ve Lee, 2009). Alba ve Hutchinson (1987) ise, ürün bilgisini aşinalık ve uzmanlık olarak iki farklı bileşene ayırmıştır. Aşinalık, tüketicinin zamanla ürün ile ilgili kazandığı deneyimlerin miktarı olarak tanımlanırken uzmanlık, ürünle ilgili görevleri başarıyla yerine getirebilme yeteneği olarak tanımlanır. Genel olarak, ürüne olan aşinalıkların artması tüketici uzmanlığının artmasına neden olur. Brucks (1985), ürün bilgisinin tüketicilerin anıları ve öğrendikleri bilgilere dayandığını belirtmektedir. Aynı zamanda, ürün bilgisini öznel, nesnel ve deneyim temelli bilgi olarak üçe ayırmıştır. Lin ve Zhen (2005) ürün bilgisinin tüketici bilincine, tüketicinin ürün hakkındaki anlayışına veya tüketici güvenine dayandığını ileri sürmüştür. Friedman ve Smith (1993) ve Lin Chen (2006) yapmış oldukları araştırmalarda, tüketicinin ilgilenim düzeyinin artmasıyla ürün ile ilgili daha fazla bilgi arayacağını belirtmiştir. Petty vd., (1983), yüksek ilgilenim düzeyine sahip tüketicilerin, düşük ilgilenim düzeyine sahip tüketicilere göre marka tutumu ve satın alma niyeti konusunda daha yüksek korelasyona sahip olduğu sonucuna varmıştır. Satın alma sürecinde, tüketicinin bir ürün hakkında sahip olduğu bilgi miktarı, bilgi arama davranışını, bilgi ve karar süreçlerini etkilemekle kalmaz, aynı zamanda bilgi ve karar süreçlerini de etkiler (Brucks, 1985). Dolayısıyla, Chao ve Rajendran (1993), müşterilerin karar verme aşamasında, mal veya hizmet satın almadan daha fazla araştırma yaptıklarını belirtmiş̧ir. Bunun yanı sıra, ürün bilgisi, tüketici satın alma niyetini (Lin ve Chen, 2006) ve marka sadakatini de etkilemektedir.

Kapferer ve Laurent (1993) kişinin kendini ifade etme derecesi olarak gördüğü sembolik değeri, ürün seçiminde başkalarına kendisi hakkında ne derece bilgi verdiğini göstermektedir diye ifade etmiştir. Bir markayı başka bir marka yerine seçmenin ve kullanmanın tüketicinin kendini ifade etmesine, kendisinin kime benzediğini ve neye inandığını göstermesine yardımcı olur (Mittal ve Lee, 1989). Kristensen, Martensen ve Gronholdt (1999), sembolik değerin ürün ilgilenimini açıklamada önemli bir unsur olarak görmektedir.

Samiee (1994) menşe kavramını, bir üreticinin ürün veya markasının ilişkili olduğu ülkeye işaret ettiğini belirtmektedir. Bir ürünün menşei ülkesi "imalat veya montaj yapılan ülke" olarak tanımlanmış olup "made in" veya "manufactured in" gibi etiketlerle gösterilmiştir (Bilkey ve Nes, 1982). Roth ve Romeo (1992) bir ülke ürünleri konusunda olumlu bir imaj ile tanınıyorsa, tüketici bu ülkedeki ürünler için daha yüksek bir satın alma niyetine sahip olacağını belirtirken, Lin ve Chen (2006) ürün menşei farkındalığı tüketicinin satın alma kararında belirgin bir pozitif etkiye sahip olduğu sonucuna varmıştır.

Kapferer ve Laurent (1985)'in Tüketici İlgilenimi Profili'ne göre haz, diğer bir ifade ile hedonik değer, bir ürünle tüketici ilgilenimini açıklamak için kullanılabilecek beş özellikten biridir. Hedonik değer, bir tür eğlence duyma ve hayal kurma eylemi gibi deneyimsel faydanın genel bir değerlendirmesi olarak tanımlarken (Overby ve Lee, 2006), Bellenger vd., (1976) ve Babin vd., (1994), hedonik değeri alışveriş faaliyetleri yoluyla zevk ve duygusal değer elde etme olarak tanımlamaktadırlar. Wirtz ve Lee (2003)'e göre, ürünlerin hedonik değerleri müşteriler tarafından bir ürünün doğal olarak hoşa giden özellikleriyle elde edilmektedir.

Kapferer ve Laurent (1993)'in beş boyutlu Tüketici İlgilenimi Profili Ölçeği'nden biri olan ilgi, ürün kategorisinin önemi olarak ifade edilmektedir. Illgi faktörünün ürün kategorisiyle arasında kalıcı bir ilişki olduğunu belirten yazar, ilgiyi bir kişinin bir üründe sahip olduğu kişisel ilgi olarak tanımlamıştır.

Kapferer ve Laurent (1993)'in beş boyutlu Tüketici ilgilenimi Profili Ölçeği'nden biri olan hata olasılığı, ürünün yanlış satın alma olasılığı olarak ifade edilmiştir (Laurent ve Kapferer, 1985). 
Risk, yanlış bir satın almanın olumsuz sonucu olarak tanımlanmıştır (Laurent ve Kapferer, 1985). Bir başka tanıma göre risk, bir markanın seçimi ile diğer markayı seçmeyiş durumunda fırsat kaybının oluşmasıdır (Mittal ve Lee, 1989). Kapferer ve Laurent (1985) riski, herhangi bir ürün ile ilgili önemli bir faktör olarak tanımlamıştır.

\section{VERI VE YÖNTEM}

\subsection{Araştırmanın Amacı ve Önemi}

İşletmeler, var oluş amaçları doğrultusunda yaşamlarını sürdürebilmek için çeşitli faaliyetlerde bulunurlar. Bu var oluş amaçları işletmeden işletmeye farklılık göstermektedir. Ancak tüm işletmelerin ortak amacı uzun dönemde hayatta kalabilmeyi sağlamaktır. Bunun için de işletmeler sahip oldukları markalar üzerinde sadakat yaratmak istemektedir. Marka sadakati yaratmak için de tüketicilerin markaya olan ilgilenim düzeylerinin anlaşılmasında büyük yarar vardır. Tüketici davranışlarının anlaşılması için gerekli olan ürün ilgilenimi marka sadakati konusunda önemli bir faktördür. Bu çalışmada, cep telefonu kullanıcılarının kullandıkları markaya olan ilgilenim faktörlerinin işletmelerin marka sadakati üzerindeki etkisi incelenmiştir. İlk olarak, marka sadakatine etki eden faktörler için literatür araştırması yapılmış ve bu faktörlerin her biri detaylı bir şekilde ele alınmıştır. Ürünlere olan ilgilenimin ilgi, haz, sembolik değer, risk, hata olasılığı, ürün menşei farkındalı̆̆ı, ürün bilgisi ve ürün özellikleri bilincinin marka sadakati üzerinde etkisinin olup olmadığı incelenen bu araştırmada hipotezler de bu amaca göre düzenlenmiştir.

\subsection{Araştırma Yöntemi}

Araştırmada kullanılan anket formunun hazırlanmasında sosyal bilimlerde yaygın bir şekilde kullanılan Likert tipi ölçekten yararlanılmıştır. Anket 10 kısımdan oluşmaktadır. Anketin birinci, ikinci, üçüncü dördüncü ve beşinci soru kısmını oluşturan ilgi, haz, sembolik değer, risk önemi ve hata olasılığı boyutları, orijinali Kapferer ve Laurent (1993) tarafından geliştirilen Tüketici Illgilenimi Profili Ölçeği'nden (Consumer Involvement Profile-CIP) yararlanılmıştır

Ölçeğin orijinalinin Fransızca olması nedeniyle İngilizce diline çevrilmiş hali Rodgers ve Schneider (1993) tarafından yapılan çalışma kaynak olarak kullanılmıştır. Araştırma anketinin altıncı, yedinci, sekizinci ve dokuzuncu kısmını oluşturan ürün menşei farkındalığı, ürün bilgisi, ürün özellikleri bilinci ve marka sadakati boyutları Nguyen (2013) çalışmasından uyarlanmıştır

Verilerin analizi ve karşılaştırılması için SPSS 21 yazılımı kullanılmıştır. Anket güvenilirliği için Cronbach'ın $\alpha$ değeri ve yapı geçerliliği için açıklayıcı faktör analizi kullanılmıştır. Araştırmanın hipotezlerini test etmek için t-testi, tek yönlü varyans analizi, çoklu regresyon analizi ve korelasyon kullanılmış ve sonuçlar yorumlanmıştır.

\subsection{Araştırmanın Evreni ve Örneklemi}

Katılımcılar 18 yaş ve üzeri Aydın'da ikamet eden cep telefonu kullanıııları ve toplumun her kesiminden öğrenciler, özel sektör ve kamu personeli ve orta ve üst sınıfa ait tüketicilerden oluşmaktadır. Bunun yanı sıra, eğitim, aylık kişisel gelir ve sosyal statüleri farklı katılıcımların olması çalışmanın kapsamını genişletmektedir. Aydın ilinde yaklaşık 1 milyon kişi yaşamaktadır. Kolayda örnekleme yöntemi ile anketlerin paylaşımı ve dağııımı ilçeler baz alınarak yapılmıştır. Örneklem büyüklüğü ile ilgili olarak, 400'ü verimli olan 440 anket dağıtılmıştır. Veri toplama süresi Ocak ve Nisan ayları arasında yaklaşık üç ay sürmüştür. Toplamda 400 anket araştırmaya dahil edilmiştir.

\section{BULGULAR VE TARTIŞMA}

\subsection{Demografik Bulgular, Katılımcı Profili}

Araştırma kapsamında değerlendirmeye alınan 400 kişiye ait demografik bulgular Tablo 1'de verilmiştir. Tablo 1 incelendiğinde erkekler 206 katılımcı ile toplam örneklemin \%51,5'ini oluştururken kadınlar ise 194 katılımcı ile toplam örneklemin \%48,5'lik kısmını oluşturmaktadır.

Tablo 1 incelenendiğinde katılımcıların 240'si bekar, toplam örneklemin \%60'ını oluştururken katılımcıların 160'ı evli olup toplam örneklemin $\% 40$ 'ını oluşturmaktadır.

Araştırmaya katılanların yaş grupları incelendiğinde 26 ile 33 yaş arası neredeyse örneklemin yarısını karşılamaktadır. Yani, bu yaş grubunda 186 kişi ankete katılmıştır. 18-25 yaşları arasındaki 108 katılımcının çoğu neredeyse öğrenciydi ve toplam örneklemin \%27'sini karşılamaktadır. Diğer dört grup: 34-41 yaş arası 44 kişi $(\% 11,0), 42-49$ yaş arası 32 kişi $(\% 8,0)$ ve 50-57 yaş arası 30 kişi $(\% 7,5)$.

Katılımcıların aylık kişisel gelir dağııımı incelendiğinde \%23,5'lik kesim 1000TL'nin altında bir aylık kişisel gelire sahip, \%21'lik kesim 1001TL-2000TL arası, 2001-3000TL arası aylık kişisel gelire sahip olanların oranı ise \%22 olarak tespit edilmiştir. Diğer 
aylık kişisel gelir dağılımları incelendiğinde; 3001TL-4000TL arası aylık kişisel gelire sahip 34 kişi (\%8,5), 4001TL-5000TL arası aylık kişisel gelire sahip 54 kişi $(\% 13,5)$ bulunmaktadır. 5001TL-6000TL arası aylık gelire sahip 16 kişi $(\% 4,0) 6001 T L$ ve üzeri aylık kişisel gelire sahip 30 kişi $(\% 7,5)$ olarak tespit edilmiştir.

Araştırmaya katılanların eğitim düzeyi incelendiğinde lisans seviyesi 186 kişi ile $(\% 46,5)$ neredeyse örneklemin yarısını karşılamaktadır. Diğer sonuçlar incelendiğinde, 86 kişi ile $(\% 21,5)$ yüksek lisans, 76 kişi ile $(\% 19)$ ilköğretim/lise, 26 kişi ile $(\% 6,5)$ doktora ve 26 kişi $(\% 6,5)$ ile yüksek okul olarak tespit edilmiştir. Bu çalışmada katılımcıların 142 kişi ile \%35,5'i özel sektör çalışanı, 116 kişi ile \%29'u öğrenci, 114 kişi ile \%28,5'i ise kamu çalışanı olarak tespit edilmiştir. Diğer sonuçlara bakıldığında, 12 kişi ile \%3,0'ünün herhangi bir yerde çalışmadığı, 10 kişi ile \%2,5'i ev hanımı ve son olarak 6 kişi ile \%1,5’i emekli olarak tespit edilmiştir.

Tablo 1: Katılımcıların Demografik Özellikleri

\begin{tabular}{|c|c|c|}
\hline & Sayı (n) & Yüzde (\%) \\
\hline \multicolumn{3}{|c|}{ Cinsiyet } \\
\hline Kadın & 194 & 48,5 \\
\hline Erkek & 206 & 51,5 \\
\hline Toplam & 400 & 100,0 \\
\hline \multicolumn{3}{|c|}{ Medeni Durum } \\
\hline Bekar & 240 & 57,0 \\
\hline Evli & 160 & 40,0 \\
\hline Toplam & 400 & 100,0 \\
\hline \multicolumn{3}{|l|}{ Yaş } \\
\hline $18-25$ yaş arası & 108 & 27,0 \\
\hline $26-33$ yaş arası & 186 & 46,5 \\
\hline 34-41 yaş arası & 44 & 11,0 \\
\hline $42-49$ yaş arası & 32 & 8,0 \\
\hline 50-50 yaş üzeri & 30 & 7,5 \\
\hline Toplam & 400 & 100,0 \\
\hline \multicolumn{3}{|c|}{ Aylık Kişisel Gelir } \\
\hline 1000TL ve Altı & 94 & 23,5 \\
\hline 1001TL-2000TL Arası & 84 & 21,0 \\
\hline 2001TL-3000TL Arası & 88 & 22,0 \\
\hline 3001TL-4000TL Arası & 34 & 8,5 \\
\hline 4001TL-5000TL Arası & 54 & 13,5 \\
\hline 5001TL-6000TL Arası & 16 & 4,0 \\
\hline 6001TL ve Üzeri & 30 & 7,5 \\
\hline Toplam & 400 & 100,0 \\
\hline \multicolumn{3}{|c|}{ Eğitim Durumu } \\
\hline İlköğretim/Lise & 76 & 19,0 \\
\hline Yüksek Okul & 26 & 6,5 \\
\hline Lisans & 186 & 46,5 \\
\hline Yüksek Lisans & 86 & 21,5 \\
\hline Doktora & 26 & 6,5 \\
\hline Toplam & 400 & 100,0 \\
\hline \multicolumn{3}{|c|}{ Meslek } \\
\hline Özel Sektör & 142 & 35,5 \\
\hline Öğrenci & 116 & 29,0 \\
\hline Kamu Çalışanı & 114 & 28,5 \\
\hline Emekli/Ev Hanımı/Işsiz & 28 & 7,0 \\
\hline Toplam & 400 & 100,0 \\
\hline
\end{tabular}

\subsection{Katılımcıların Cep Telefonu Kullanımına İlişkin Bulgular}

Araştırmaya katılan 400 tüketicinin cep telefon kullanımına ilişkin verileri aşağıda verilmiştir. Tablo 2 incelendiğinde katılımcıların \%84'ü cep telefonu alırken markaya dikkat ettiklerini ve s adlıları cep telef markanın cep telef.... Önemli oldugn belirtmişlerdir. markaya dikkat etmeyen diğer katılımcılar ise bu katılımcılar cep telefonu satın alırken kendilerine yakın buldukları, ihtiyaçlarını karşılayabilecek veya satış elamanı tarafından kendilerine önerilen herhangi bir marka cep telefonunu satın almaktadırlar. Katılımcıların hali hazırda kullanmış oldukları cep telefonu markaları incelendiğinde 400 
katılımcı arasında 14 farklı cep telefonu markasını kullandıkları belirlenmiştir. Bu çalışma kapsamında Samsung ve Apple'ın en popüler cep telefonu markaları olduğu sonucu beklenen bir sonuçtur. Daha spesifik olmak gerekirse, Apple marka cep telefonu kullanan 186, Samsung marka cep telefonu kullanan ise 136 kişidir. Tablo 2'de görüleceği üzere, Apple ve Samsung markalarının genel marka kullanımının sırasıyla \%46,5 ve \%34'lük bölümünü karşıladığı sonucuna ulaşılmıştır. Bu sonuç, 2016 yılının verilerine göre düzenlenen IDC (2017)'nin raporu ile benzerlik göstermektedir. Ayrıca, araştırmadaki diğer cep telefonu markaları örneklemin \%19,5'ini kapsamaktadır. Bu dilimde sadece, LG, General Mobile, HTC, Lenovo, Sony, Turkcell, Asus, Nokia, Vestel, Casper, Huawei, Vodafone markaları bulunmaktadır. Kısacası, ankete katılanların kullandığı cep telefonu markalarındaki tanımlayıcı istatistiklerin sonucu, bu araştırmada ankete katılanların cep telefonunu kullanma eğiliminin Türkiye'de ve hatta dünyada cep telefonu markası eğilimi ile benzer olduğunu ispatlamaktadır. Katılımcıların cep telefonlarını nereden temin ettiği incelendiğinde $\% 62,5^{\prime}$ lik kesim cep telefonlarını alışveriş merkezlerinden temin ettiklerini belirtmişlerdir. Alım güçleri sınırlı olan ve maddi olarak ailelerine bağımlı olan öğrencilerin yüksek bir bölümünü oluşturduğu düşünülen $\% 13,0^{\prime} l u ̈ k$ kesim cep telefonunun hediye olduğunu belirtmişlerdir. \%4,5'lik kesim ise cep telefonlarının ikinci el olduğunu, \%4,0'lük kesim ise İnternet üzerinden temin ettiklerini ve geri kalan kesim ise diğer seçeneğini işaretlemişlerdir. Katılımcıların şuan ki cep telefonlarını ne kadar süredir kullandıkları incelendiğinde \%32'lik bölümü, hali hazırda kullanmış oldukları cep telefonlarını 6ay-1yıl arası bir süredir kullandıklarını belirtmiştir.

Tablo 2: Katılımcıların Cep Telefon Kullanımına ilişkin Frekans Dağıımları

\begin{tabular}{|c|c|c|}
\hline & Sayı (N) & Yüzde (\%) \\
\hline \multicolumn{3}{|c|}{ Marka Tercih Sebebi midir? } \\
\hline Evet & 336 & 84,0 \\
\hline Hayır & 64 & 16,0 \\
\hline Toplam & 400 & 100,0 \\
\hline \multicolumn{3}{|c|}{ Marka } \\
\hline Apple & 186 & 46,5 \\
\hline Samsung & 136 & 34,0 \\
\hline Diğer & 78 & 19,5 \\
\hline Toplam & 400 & 100,0 \\
\hline \multicolumn{3}{|c|}{ Cep Telefonu Temin Edilme Şekli } \\
\hline Alışveriş Merkezi & 250 & 62,5 \\
\hline Hediye & 52 & 13,0 \\
\hline İkinci El & 18 & 4,5 \\
\hline İnternet & 16 & 4,0 \\
\hline Diğer & 64 & 16,0 \\
\hline Toplam & 400 & 100,0 \\
\hline \multicolumn{3}{|c|}{ Cep Telefonu Değiştirme Sıklığı } \\
\hline 6 aydan kısa bir süre & 66 & 16,5 \\
\hline $6 a y-1 y ı l$ & 128 & 32,0 \\
\hline $13 a y-2 y ı l$ & 100 & 25,0 \\
\hline 25ay-3yıl & 64 & 16,0 \\
\hline 3 yıldan fazla bir süre & 42 & 10,5 \\
\hline Toplam & 400 & 100,0 \\
\hline
\end{tabular}

\subsection{Faktör Analizi}

Araştırmaya katılan tüketicilerin kullandıkları markaya olan ilgilenimini ölçmek üzere oluşturulan ölçek maddelerine faktör analizi yapılıp yapılamayacağını kontrol etmek amacıyla KMO değerinden ve Bartlett testinden yararlanılmıştır. KMO değeri 0,770 ve Bartlett testi $\alpha=0,000$ düzeyinde manidar bulunduğundan tutum ölçeğine faktör analizi uygulamak için örneklem büyüklüğünün yeterli olduğu kabul edilmiştir. Çalışmada kullanılan ölçekler için faktör sayısına karar verirken Varimax dik döndürme tekniği uygulanmış ve özdeğeri 1'den büyük olan faktörler dikkate alındığında ölçek toplamda 7 faktörlü olarak belirlenmiştir. Birinci faktör yüklerinden ilgi boyutunda bulunan "cep telefonuna kayıtsız kalııı" ifadesinin faktör yükü 0,30'dan düşük olduğu için analiz dışında bırakılmıştır. Hata olasılığı faktöründe bulunan "bir cep telefonu seçmek oldukça zor bir iştir" ifadesi faktör analizi sonuçlarına göre çalışmanın bir diğer faktörü olan risk önemi faktörüne dahil edilmiştir. Risk önemi faktöründe bulunan "bir cep telefonu seçerken yanlış bir karar verirsem, bu çok da önemli değildir" ifadesinin faktör yükü 0,30'dan düşük olduğu için analiz dışında bırakılmıştır. Bunlara ek olarak, ürün bilgisi faktörü altında bulunan iki ifadenin (cep telefonumu nası kullanacağımı ve koruyacağımı bilirim ile cep telefonum ile ilgili çıkan haberleri ve gelişmeleri takip ederim) faktör yükü 0,30'dan düşük olduğu için analiz dışında bırakılmıştır. 
İlgilenimi ölçen ilgi ve haz faktörleri ölçeğin uyarlandığı çalışmada olduğu gibi bu çalışmada da aynı faktör altında toplanmıştır. Bu iki faktör, birbirine bağlıdır ve tek bir faktörde bilrleşmektedir. Dolayısıyla, Kapferer ve Laurent (1993)'in yapmış olduğu çalışma ile bu çalışma paralellik göstermektedir. Ölçeğin açıklanan varyansı faktör 1 için \%13,838 faktör 2 için \%11,104, faktör 3 için \%10,306, faktör 4 için \%9,838, faktör 5 için \%8,401, faktör 6 için \%8,313, faktör 7 için \%6,358`dir. Açıklanan toplam varyans ise \%68,159'dur. Faktör analizinin ardından ölçeğin güvenilirliği test edilmiştir. Ölçeğin Cronbach's Alpha değeri 0,825 olarak tespit edilmiş, güvenilirliğin faktörlere göre dağılımları ise Tablo-3'de belirtilmiştir. Güvenilirlik analizi sonucunda, toplanan verilerin hipotez testlerine uygun analizlerle analiz edilebileceğine karar verilmiştir. Önermelerin faktörlere göre dağılımları, açıklanan varyansları ve faktör güvenilirlikleri Tablo 3'te özetlenmiştir.

Tablo 3: Faktör Analizine Göre Faktör Yükleri, Açıklanan Varyans Ve Faktör Güvenilirliği

\begin{tabular}{|c|c|c|c|c|c|}
\hline & $\mu$ & $\mathbf{s}$ & $\begin{array}{l}\text { Faktör } \\
\text { Yükü }\end{array}$ & $\begin{array}{l}\text { Açıklanan } \\
\text { Varyans }\end{array}$ & $\begin{array}{l}\text { Cronbach's } \\
\text { Alpha }\end{array}$ \\
\hline İgi ve Haz & 3,20 & 0,91 & & 13,838 & 0,857 \\
\hline Cep telefonuna oldukça ilgi duyarım & 3,22 & 1,163 & 0,812 & & \\
\hline Cep telefonuna çok önem veririm & 3,46 & 1,154 & 0,758 & & \\
\hline Cep telefonumu kullanırken farklı hissederim & 2,67 & 1,190 & 0,706 & & \\
\hline $\begin{array}{l}\text { Bir cep telefonu satın almak insanın kendisine hediye vermesi } \\
\text { gibidir }\end{array}$ & 3,06 & 1,271 & 0,702 & & \\
\hline Kendim için cep telefonu satın almaktan zevk alırım & 3,09 & 1,333 & 0,701 & & \\
\hline Bir cep telefonuna sahip olmak beni mutlu eder & 3,75 & 1,034 & 0,700 & & \\
\hline Sembolik Değer & 2,45 & 1,03 & & 11,104 & 0,860 \\
\hline $\begin{array}{l}\text { Kişinin seçtiği cep telefonu onun kim olduğu hakkında ipuçları } \\
\text { verir }\end{array}$ & 2,53 & 1,214 & 0,892 & & \\
\hline $\begin{array}{l}\text { Kişinin seçtiği cep telefonuna bakarak onun hakkında bir şeyler } \\
\text { söylenebilir }\end{array}$ & 2,61 & 1,180 & 0,868 & & \\
\hline Bence cep telefonum kişiliğimi yansıtır & 2,24 & 1,102 & 0,802 & & \\
\hline Hata Olasılığı & 2,70 & 0,87 & & 10,306 & 0,745 \\
\hline $\begin{array}{l}\text { Bir cep telefonu satın aldığında doğru bir seçim yaptığına emin } \\
\text { olamazsın }\end{array}$ & 2,84 & 1,094 & 0,807 & & \\
\hline $\begin{array}{l}\text { Cep telefonu satın aldığınızda bu ürünün sizin satın almanız } \\
\text { gereken bir cep telefonu olup olmadığını hiçbir zaman } \\
\text { bilemezsiniz }\end{array}$ & 2,55 & 1,054 & 0,805 & & \\
\hline $\begin{array}{l}\text { Birçok cep telefonu seçeneği arasından birini seçtiğimde, doğru } \\
\text { bir seçim yapıp yapmadığım konusunda kararsız kalırım }\end{array}$ & 2,71 & 1,081 & 0,647 & & \\
\hline Risk Önemi & 3,47 & 0,83 & & 9,838 & 0,546 \\
\hline $\begin{array}{l}\text { Gereksinimlerimi karşılamayan bir cep telefonu satın almak } \\
\text { gerçekten sinir bozucu bir durumdur }\end{array}$ & 3,85 & 1,077 & 0,697 & & \\
\hline $\begin{array}{l}\text { Bir cep telefonu satın aldıktan sonra yanlış bir seçim yaparsam } \\
\text { çok üzülürüm }\end{array}$ & 3,61 & 1,180 & 0,684 & & \\
\hline Bir cep telefonu seçmek oldukça zor bir iştir & 2,96 & 1,197 & 0,578 & & \\
\hline Ürün Menşei Farkındalığı & 3,13 & 0,96 & & 8,401 & 0,844 \\
\hline $\begin{array}{l}\text { Bence cep telefonu menşei ile kalitesi arasında yakın bir ilişki } \\
\text { vardır. }\end{array}$ & 3,30 & 1,133 & 0,893 & & \\
\hline $\begin{array}{l}\text { Satın aldığım cep telefonunun menşei (üretildiği ülke) benim için } \\
\text { oldukça önemlidir }\end{array}$ & 2,95 & 1,200 & 0,849 & & \\
\hline Cep telefonumun menşei bana güven verir & 3,14 & 1,164 & 0,811 & & \\
\hline $\begin{array}{l}\text { Gelişmiş ülkede üretilmiş bir cep telefonu daha az gelişmiş } \\
\text { ülkede üretilenden iyidir }\end{array}$ & 3,16 & 1,174 & 0,690 & & \\
\hline Ürün Bilgisi & 3,60 & 0,77 & & 8,313 & 0,805 \\
\hline $\begin{array}{l}\text { Eğer başkaları cep telefonum hakkında görüşlerimi sorarsa, } \\
\text { onlara tavsiyelerde bulunabilirim }\end{array}$ & 3,85 & 0,980 & 0,794 & & \\
\hline Cep telefonum hakkında yeterli bilgiye sahibim & 3,79 & 0,906 & 0,769 & & \\
\hline $\begin{array}{l}\text { Cep telefonum hakkında konuşulurken karşımdakinin teknik } \\
\text { bilgisinden emin olabilirim }\end{array}$ & 3,21 & 1,139 & 0,683 & & \\
\hline $\begin{array}{l}\text { Cep telefonum ile ilgili çıkan haberleri veya gelişmeleri takip } \\
\text { ederim }\end{array}$ & 3,36 & 1,150 & 0,621 & & \\
\hline $\begin{array}{l}\text { Satın almadan önce cep telefonum hakkında teknik bilgileri } \\
\text { öğrendim }\end{array}$ & 3,84 & 0,970 & 0,578 & & \\
\hline Ürün Özellikleri Bilinci & 3,74 & 0,84 & & 6,358 & 0,783 \\
\hline
\end{tabular}




\begin{tabular}{|c|c|c|c|c|c|}
\hline Cep telefonum kolay kolay bakıma gerek duymaz & 3,57 & 1,057 & 0,848 & & \\
\hline Cep telefonum çok düzgün çalışıyor & 3,61 & 1,105 & 0,817 & & \\
\hline Cep telefonu benim ihtiyaçlarıma karşılık vermektedir & 4,07 & 0,850 & 0,732 & & \\
\hline TOPLAM & & & & 68,159 & 0,825 \\
\hline Bağımlı Değişken-Marka Sadakati & $3, \mathbf{5 0}$ & 0,83 & & & \\
\hline $\begin{array}{l}\text { Bir cep telefonu satın alırken diğer markaların cep telefonlarına } \\
\text { da dikkat ederim }\end{array}$ & 3,80 & 1,045 & & & \\
\hline $\begin{array}{l}\text { Bir cep telefonu söz konusu olduğunda, kendi cep telefonumun } \\
\text { markasının ilk sırada olduğunu düşünüyorum }\end{array}$ & 3,28 & 1,226 & & & \\
\hline $\begin{array}{l}\text { Diğer markalarda benzer özelliklere sahip olsa da kendi cep } \\
\text { telefonumun markasını tercih etmeye devam edeceğim }\end{array}$ & 3,39 & 1,225 & & & \\
\hline $\begin{array}{l}\text { Eğer bir cep telefonu daha alacak olursam ya da mevcut cep } \\
\text { telefonumu değiştirmem gerekirse yine aynı marka cep } \\
\text { telefonunu satın alırım }\end{array}$ & 3,41 & 1,239 & & & \\
\hline $\begin{array}{l}\text { Eğer bazıları satın aldığım cep telefonu hakkında benim } \\
\text { görüşlerime başvurursa, kullandığım cep telefonu markasını } \\
\text { tavsiye edeceğim }\end{array}$ & 3,65 & 1,154 & & & \\
\hline
\end{tabular}

\subsection{Araştırma Modeli, Hipotez Testleri ve Analizler}

Kullanıcıların cep telefonlarına olan ilgileniminin marka sadakati üzerindeki etkisinin incelenmesi amaçlanan bu çalışmanın modeli Şekil-1'de gösterilmiştir:

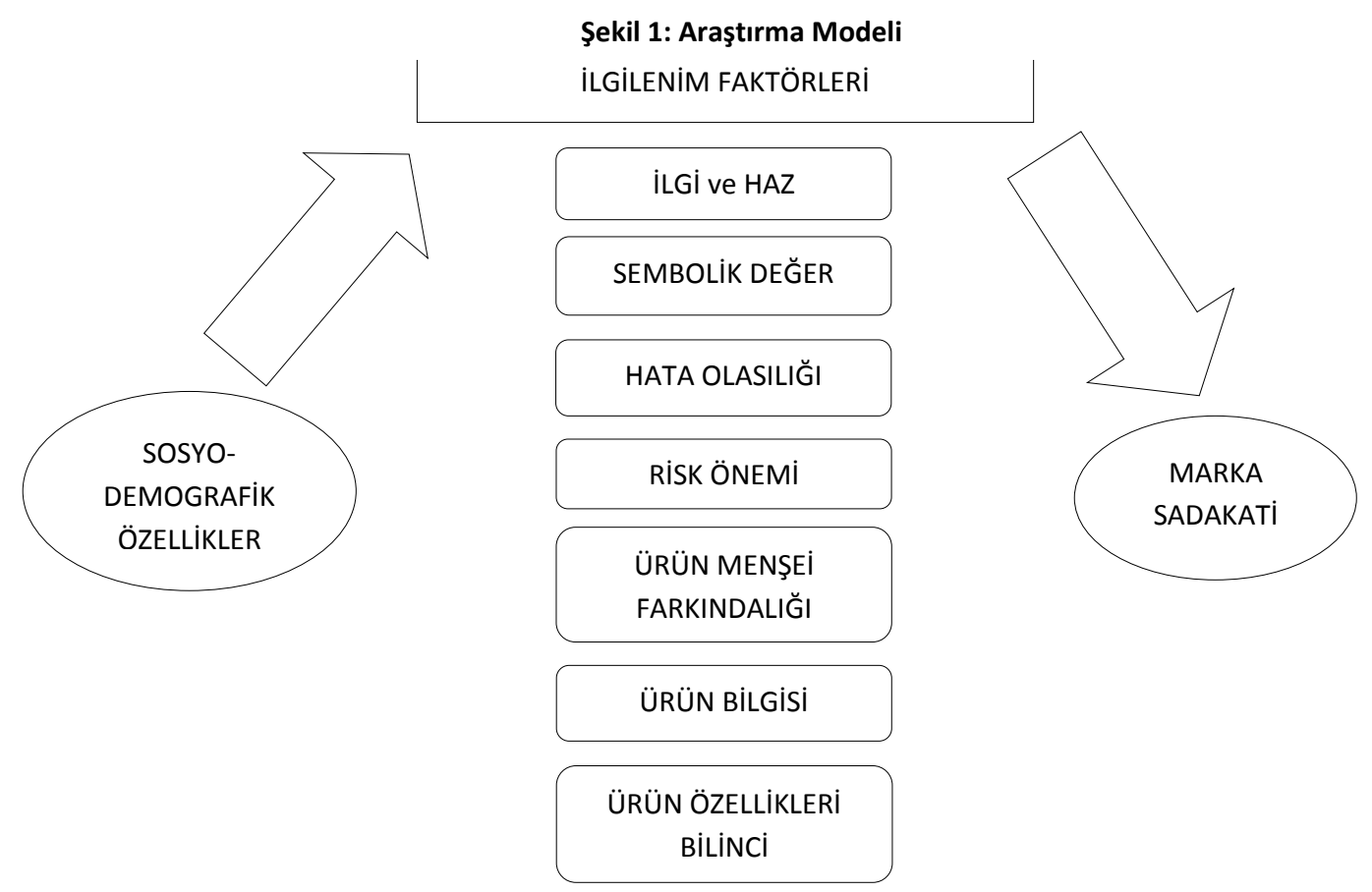

Katılımcıların cep telefonu alımlarında markanın tercih sebebi olup olmaması ile cinsiyet, medeni durum, yaş, aylık kişisel gelir, eğitim durumu ve meslekleri arasındaki ilişkiyi incelemek için Ki-kare testi uygulanmıştır. Cinsiyet ve medeni durum ile ilgilenim boyutları arasındaki farklılı̆ın tespitinde bağımsız gruplar için t-testi; yaş, gelir, eğitim durumu, meslek, cep telefonu değiştirme sıklığı ve cep telefonu markası ile ilgilenim boyutları arasındaki farklılı̆ın tespiti için ise tek yönlü varyans analizi (ANOVA) uygulanmıştır. 
Tablo 4: Katılımcıların Cep Telefonu Alımlarında Markanın Tercih Sebebi Olup OImaması İle Cinsiyet Faktörü Dağılım Tablosu

\begin{tabular}{cccc}
\hline & Evet & Hayır & Toplam \\
\hline Kadın & 168 & 26 & 194 \\
& $\% 86,6$ & $\% 13,4$ & $\% 100$ \\
& $\% 42,0$ & $\% 6,5$ & $\% 48,5$ \\
\hline \multirow{2}{*}{ Erkek } & 168 & 38 & 206 \\
& $\% 81,6$ & $\% 18,4$ & $\% 100$ \\
& $\% 42,0$ & $\% 9,5$ & $\% 51,5$ \\
\hline Toplam & 336 & 64 & 400 \\
& $\% 84$ & $\% 16$ & $\% 100$ \\
\hline
\end{tabular}

H0: Katılımcıların cinsiyetleri ile cep telefonu satın alımlarında marka faktörünün bir tercih sebebi olup olmaması arasında bir ilişki yoktur.

H1: Katılımcıların cinsiyetleri ile cep telefonu satın alımlarında marka faktörünün bir tercih sebebi olup olmaması arasında bir ilişki vardır.

Ki-Kare testi yardımıyla incelenen hipotezler Ki-Kare değeri 1,892, serbestlik derecesi 1 ve p değeri 0,107 olarak bulunmuştur. Hipotez testi uygulanırken 0,05 anlamlıık düzeyi kabul edilerek işlemler yapılmıştır. Buna göre elde edilen $\mathrm{p}$ değeri anlamlıık düzeyi olan 0,05"ten büyük olduğundan HO rededilemez. Yani katılımcıların cinsiyetleri ile cep telefonu satın alımlarında marka faktörünün bir tercih sebebi olup olmaması arasında bir ilişki yoktur.

Tablo 5: Katılımcıların Cep Telefonu Alımlarında Markanın Tercih Sebebi Olup Olmaması İle Medeni Durumları Faktörü Dağılım Tablosu

\begin{tabular}{cccc}
\hline & Evet & Hayır & Toplam \\
\hline \multirow{2}{*}{ Bekar } & 216 & 24 & 240 \\
& $\% 90,0$ & $\% 10,0$ & $\% 100$ \\
& $\% 54,0$ & $\% 6,0$ & $\% 60,0$ \\
\hline \multirow{2}{*}{ Evli } & 120 & 40 & 160 \\
& $\% 75,0$ & $\% 25,0$ & $\% 100$ \\
\multirow{2}{*}{ Toplam } & $\% 30,0$ & $\% 10,0$ & $\% 40,0$ \\
\hline & 336 & 64 & 400 \\
& $\% 84$ & $\% 16$ & $\% 100$ \\
\hline
\end{tabular}

H0: Katılımcıların mesleği ile cep telefonu satın alımlarında marka faktörünün bir tercih sebebi olup olmaması arasında bir ilişki yoktur.

H1: Katılımcıların mesleği ile cep telefonu satın alımlarında marka faktörünün bir tercih sebebi olup olmaması arasında bir ilişki vardır.

Yukarıdaki verilen hipotezler ki-kare testi yardımıyla incelenmiştir. Buna göre bu hipotez testine ait Ki-Kare Değeri 16,071, serbestlik derecesi 1 ve $p$ değeri 0,000 olarak elde edilmiştir. Hipotez testi uygulanırken 0,05 anlamlılık düzeyi kabul edilerek işlemler yapılmıştır. Buna göre elde edilen $p$ değeri anlamlıık düzeyi olan 0,05 "ten küçük olduğundan $\mathrm{HO}$ hipotezi rededilir. Yani katılımcıların medeni durumları ile cep telefonu satın alımlarında marka faktörünün bir tercih sebebi olup olmaması arasında bir ilişki vardır.

Tablo 6: Katılımcıların Cep Telefonu Alımlarında Markanın Tercih Sebebi Olup Olmaması İle Yaş Faktörü Dağıım Tablosu

\begin{tabular}{cccc}
\hline & Evet & Hayır & Toplam \\
\hline $\mathbf{1 8 - 2 5}$ & 100 & 8 & 108 \\
& $\% 92,6$ & $\% 7,4$ & $\% 100$ \\
& $\% 25,0$ & $\% 2,0$ & $\% 27,0$ \\
\hline \multirow{2}{26-33}{} & 160 & 26 & 186 \\
& $\% 86$ & $\% 14$ & $\% 100$ \\
& $\% 40,0$ & $\% 6,5$ & $\% 46,5$ \\
\hline \multirow{2}{*}{$34-41$} & 32 & 12 & 44 \\
& $\% 72,7$ & $\% 27,3$ & $\% 100$
\end{tabular}




\begin{tabular}{cccc} 
& $\% 8,0$ & $\% 3,0$ & $\% 11$ \\
\hline $\mathbf{4 2 - 4 9}$ & 22 & 10 & 32 \\
& $\% 68,8$ & $\% 31,3$ & $\% 100$ \\
& $\% 5,5$ & $\% 2,5$ & $\% 8,0$ \\
\hline $\mathbf{5 0 - 5 0 +}$ & 22 & 8 & 30 \\
& $\% 73,3$ & $\% 26,7$ & $\% 100$ \\
& $\% 5,5$ & $\% 2,0$ & $\% 7,5$ \\
\hline Toplam & 336 & 64 & 400 \\
& $\% 84$ & $\% 16$ & $\% 100$ \\
\hline
\end{tabular}

H0: Katılımcıların yaş grupları ile cep telefonu satın alımlarında marka faktörünün bir tercih sebebi olup olmaması arasında bir ilişki yoktur.

H1: Katılımcıların yaş grupları ile cep telefonu satın alımlarında marka faktörünün bir tercih sebebi olup olmaması arasında bir ilişki vardır.

Yukarıdaki verilen hipotezler ki-kare testi yardımıyla incelenmiştir. Buna göre bu hipotez testine ait Ki-Kare Değeri 18,736, serbestlik derecesi 4 ve $p$ değeri 0,001 olarak elde edilmiştir. Hipotez testi uygulanırken 0,05 anlamlılık düzeyi kabul edilerek işlemler yapılmıştır. Buna göre elde edilen p değeri anlamlılık düzeyi olan 0,05"ten küçük olduğundan HO hipotezi reddedilir. Yani katılımcıların yaş grupları ile cep telefonu satın alımlarında marka faktörünün bir tercih sebebi olup olmaması arasında bir ilişki vardır.

Tablo 7: Katılımcıların Cep Telefonu Alımlarında Markanın Tercih Sebebi Olup Olmaması ile Gelir Seviyesi Faktörü Dağılım Tablosu

\begin{tabular}{|c|c|c|c|}
\hline & Evet & Hayır & Toplam \\
\hline & 84 & 10 & 94 \\
\hline \multirow[t]{2}{*}{ 1000TL ve Altı } & $\% 89,4$ & $\% 10,6$ & $\% 100$ \\
\hline & $\% 21,0$ & $\% 2,5$ & $\% 23,5$ \\
\hline \multirow{3}{*}{ 1001TL-2000TL Arası } & 72 & 12 & 84 \\
\hline & $\% 85,7$ & $\% 14,3$ & $\% 100$ \\
\hline & $\% 18,0$ & $\% 3,0$ & $\% 21,0$ \\
\hline \multirow{3}{*}{ 2001TL-3000TL Arası } & 66 & 22 & 88 \\
\hline & $\% 75,0$ & $\% 25,0$ & $\% 100$ \\
\hline & $\% 16,5$ & $\% 5,5$ & $\% 22,0$ \\
\hline \multirow{3}{*}{ 3001TL-4000TL Arası } & 26 & 8 & 34 \\
\hline & $\% 76,5$ & $\% 23,5$ & $\% 100$ \\
\hline & $\% 6,5$ & $\% 2,0$ & $\% 8,5$ \\
\hline \multirow{3}{*}{ 4001TL-5000TL Arası } & 50 & 4 & 54 \\
\hline & $\% 92,6$ & $\% 7,4$ & $\% 100$ \\
\hline & $\% 12,5$ & $\% 1,0$ & $\% 13,5$ \\
\hline \multirow{3}{*}{ 5001TL-6000TL Arası } & 16 & 0 & 16 \\
\hline & $\% 100$ & $\% 0$ & $\% 100$ \\
\hline & $\% 4,0$ & $\% 0$ & $\% 4,0$ \\
\hline \multirow{3}{*}{ 6001TL ve Üzeri } & 22 & 8 & 30 \\
\hline & $\% 73,3$ & $\% 26,7$ & $\% 100$ \\
\hline & $\% 5,5$ & $\% 2,0$ & $\% 7,5$ \\
\hline \multirow{2}{*}{ Toplam } & 336 & 64 & 400 \\
\hline & $\% 84$ & $\% 16$ & $\% 100$ \\
\hline
\end{tabular}

H0: Katılımcıların aylık gelir ile cep telefonu satın alımlarında marka faktörünün bir tercih sebebi olup olmaması arasında bir ilişki yoktur.

H1: Katılımcıların aylık gelir ile cep telefonu satın alımlarında marka faktörünün bir tercih sebebi olup olmaması arasında bir ilişki vardır.

Yukarıdaki verilen hipotezler ki-kare testi yardımıyla incelenmiştir. Buna göre bu hipotez testine ait Ki-Kare Değeri 17,486, serbestlik derecesi 6 ve $p$ değeri 0,008 olarak elde edilmiştir. Hipotez testi uygulanırken 0,05 anlamlılık düzeyi kabul edilerek işlemler yapılmıştır. Buna göre elde edilen p değeri anlamlılık düzeyi olan 0,05"ten küçük olduğundan HO hipotezi reddedilir. 
Yani katılımcıların gelir seviyesi ile cep telefonu satın alımlarında marka faktörünün bir tercih sebebi olup olmaması arasında bir ilişki vardır.

Tablo 8: Katılımcıların Cep Telefonu Alımlarında Markanın Tercih Sebebi Olup Olmaması Ile Eğitim Seviyesi Faktörü Dağılım Tablosu

\begin{tabular}{cccc}
\hline & Evet & Hayır & Toplam \\
\hline \multirow{3}{*}{ ilköğretim/Lise } & 62 & 14 & 76 \\
& $\% 81,6$ & $\% 18,4$ & $\% 100$ \\
Yüksekokul & $\% 15,5$ & $\% 3,5$ & $\% 19,0$ \\
& 22 & 4 & 26 \\
& $\% 84,6$ & $\% 15,4$ & $\% 100$ \\
Lisans & $\% 5,5$ & $\% 1,0$ & $\% 6,5$ \\
& 156 & 30 & 186 \\
Yüksek Lisans & $\% 83,9$ & $\% 16,1$ & $\% 100$ \\
& $\% 39,0$ & $\% 7,5$ & $\% 46,5$ \\
& 78 & 8 & 86 \\
Doktora & $\% 90,7$ & $\% 9,3$ & $\% 100$ \\
& $\% 19,5$ & $\% 2,0$ & $\% 21,5$ \\
Toplam & 18 & 8 & 26 \\
& $\% 69,2$ & $\% 30,8$ & $\% 100$ \\
& 336 & $\% 2,0$ & $\% 6,5$ \\
\end{tabular}

H0: Katılımcıların eğitim seviyesi ile cep telefonu satın alımlarında marka faktörünün bir tercih sebebi olup olmaması arasında bir ilişki yoktur.

H1: Katılımcıların eğitim seviyesi ile cep telefonu satın alımlarında marka faktörünün bir tercih sebebi olup olmaması arasında bir ilişki vardır.

Yukarıdaki verilen hipotezler ki-kare testi yardımıyla incelenmiştir. Buna göre bu hipotez testine ait Ki-Kare Değeri 7,431, serbestlik derecesi 4 ve $p$ değeri 0,115 olarak elde edilmiştir. Hipotez testi uygulanırken 0,05 anlamlıık düzeyi kabul edilerek işlemler yapılmıştır. Buna göre elde edilen p değeri anlamlılık düzeyi olan 0,05”ten büyük olduğundan HO hipotezi kabul edilir. Yani katıımcıların eğitim seviyesi ile cep telefonu satın alımlarında marka faktörünün bir tercih sebebi olup olmaması arasında bir ilişki yoktur.

Tablo 9: Katılımcıların Cep Telefonu Alımlarında Markanın Tercih Sebebi Olup Olmaması Ile Meslek Faktörü Dağılım Tablosu

\begin{tabular}{cccc}
\hline & Evet & Hayır & Toplam \\
\hline \multirow{2}{*}{ Özel Sektör } & 90 & 24 & 114 \\
& $\% 78,9$ & $\% 21,1$ & $\% 100$ \\
& $\% 22,5$ & $\% 6,0$ & $\% 28,5$ \\
Öğrenci & 118 & 24 & 142 \\
& $\% 83,1$ & $\% 16,9$ & $\% 100$ \\
Kamu Çalışanı & $\% 29,5$ & $\% 6,0$ & $\% 35,5$ \\
& 6 & 0 & 6 \\
Çalışmıyor & $\% 100$ & $\% 0$ & $\% 100$ \\
& $\% 1,5$ & $\% 0,0$ & $\% 1,5$ \\
Toplam & 122 & 16 & 138 \\
& $\% 88,4$ & $\% 11,6$ & $\% 100$ \\
& 330,5 & $\% 4,0$ & $\% 34,5$ \\
\end{tabular}

H0: Katılımcıların mesleği ile cep telefonu satın alımlarında marka faktörünün bir tercih sebebi olup olmaması arasında bir ilişki yoktur. 
H1: Katılımcıların mesleği ile cep telefonu satın alımlarında marka faktörünün bir tercih sebebi olup olmaması arasında bir ilişki vardır.

Yukarıdaki verilen hipotezler ki-kare testi yardımıyla incelenmiştir. Buna göre bu hipotez testine ait Ki-Kare Değeri 5,387, serbestlik derecesi 3 ve $p$ değeri 0,146 olarak elde edilmiştir. Hipotez testi uygulanırken 0,05 anlamlılık düzeyi kabul edilerek işlemler yapılmıştır. Buna göre elde edilen p değeri anlamlılık düzeyi olan 0,05”ten büyük olduğundan HO hipotezi kabul edilir. Yani katılımcıların eğitim seviyesi ile cep telefonu satın alımlarında marka faktörünün bir tercih sebebi olup olmaması arasında bir ilişki yoktur.

Tablo 10: Katılımcıların Kullandıkları Cep Telefonu Markasını Ne Kadar Süredir Kullandığı İle Kullandıkları Cep Telefonu Markasına ilişkin Dağıım Tablosu

\begin{tabular}{|c|c|c|c|c|c|c|}
\hline & $\begin{array}{c}6 \text { Aydan Kısa Bir } \\
\text { Süredir }\end{array}$ & 6 Ay-1 Yıl & 13 Ay-2 Yıl & 25 Ay - 3 Yıl & $\begin{array}{l}3 \text { Yıldan Daha } \\
\text { FazlaSüredir }\end{array}$ & Toplam \\
\hline & 24 & 76 & 44 & 28 & 12 & 184 \\
\hline \multirow[t]{3}{*}{ Apple } & $\% 13,0$ & $\% 41,3$ & $\% 23,9$ & $\% 15,2$ & $\% 6,5$ & $\% 100$ \\
\hline & $\% 6,0$ & $\% 19,0$ & $\% 11,0$ & $\% 7,0$ & $\% 3,0$ & $\% 46,0$ \\
\hline & 30 & 32 & 28 & 22 & 24 & 136 \\
\hline \multirow[t]{3}{*}{ Samsung } & $\% 22,1$ & $\% 23,5$ & $\% 20,6$ & $\% 16,2$ & $\% 17,6$ & $\% 100$ \\
\hline & $\% 7,5$ & $\% 8,0$ & $\% 7,0$ & $\% 5,5$ & $\% 6,0$ & $\% 34,0$ \\
\hline & 12 & 20 & 28 & 14 & 6 & 80 \\
\hline \multirow[t]{2}{*}{ Diğer } & $\% 15,0$ & $\% 25,0$ & $\% 35,0$ & $\% 17,5$ & $\% 7,5$ & $\% 100,0$ \\
\hline & $\% 3,0$ & $\% 5,0$ & $\% 7,0$ & $\% 3,5$ & $\% 1,5$ & $\% 2,0$ \\
\hline \multirow{2}{*}{ Toplam } & 66 & 128 & 100 & 64 & 42 & 400 \\
\hline & $\% 16,5$ & $\% 32$ & $\% 25$ & $\% 16$ & $\% 10,5$ & $\% 100$ \\
\hline
\end{tabular}

H0: Katılımcıların kullandıkları cep telefonu markasını ne kadar süredir kullandığı ile kullandıkları cep telefonu markası arasında bir ilişki yoktur.

H1: Katılımcıların kullandıkları cep telefonu markasını ne kadar süredir kullandığı ile kullandıkları cep telefonu markası arasında bir ilişki vardır.

Yukarıdaki verilen hipotezler ki-kare testi yardımıyla incelenmiştir. Buna göre bu hipotez testine ait Ki-Kare Değeri 27,847, serbestlik derecesi 8 ve $p$ değeri 0,001 olarak elde edilmiştir. Hipotez testi uygulanırken 0,05 anlamlılık düzeyi kabul edilerek işlemler yapılmıştır. Buna göre elde edilen $p$ değeri anlamlılık düzeyi olan 0,05"ten küçük olduğundan HO hipotezi rededilir. Yani Katılımcıların kullandıkları cep telefonu markasını ne kadar süredir kullandığı ile kullandıkları cep telefonu markası arasında bir ilişki vardır.

Bağımsız örnekler için t-testi yorumlanırken varyansların homojenliği varsayımına yönelik Levene testi sonucunda $p>0,05$ olan faktörler için serbestlik derecesi 388, p<0,05 için ise 388'den farklı değerler olduğu görülmüştür. Her iki durum için de t-testi, uygunluklarına göre yorumlanmıştır.

Tablo 11: Katılımcıların Cinsiyeti Ile İlgilenim Boyutları Arasındaki Farkıılığının Tespitine Yönelik Bağımsız Örnekler İçin TTesti Tablosu

\begin{tabular}{|c|c|c|c|c|c|}
\hline & $\begin{array}{c}\text { Kadın } \\
(\mathrm{N}=194)\end{array}$ & $\begin{array}{c}\text { Erkek } \\
(\mathrm{N}=206)\end{array}$ & $\mathbf{t}$ & df & Sig. \\
\hline F1: İlgi ve Haz & 3,2698 & 3,1456 & 1,362 & 398 & 0,174 \\
\hline F2: Sembolik Değer & 2,4192 & 2,4951 & $-0,735$ & 398 & 0,463 \\
\hline F3: Hata Olasılığı & 2,8522 & 2,5566 & 3,418 & 398 & $0,001 *$ \\
\hline F4: Risk Önemi & 3,5292 & 3,4175 & 1,340 & 398 & 0,181 \\
\hline F5: Ürün Menşei Farkındalığı & 3,2629 & 3,0194 & 2,541 & 398 & $0,011^{*}$ \\
\hline F6: Ürün Bilgisi & 3,5113 & 3,6951 & $-2,387$ & 398 & 0,017 \\
\hline F7: Ürün Özellikleri Bilinci & 3,6564 & 3,8317 & $-2,069$ & 359,471 & $0,039 *$ \\
\hline
\end{tabular}

Faktör analizi sonucunda elde edilen yedi faktöre ait ortalamalarda kadınlar ile erkekler arasında anlamlı bir fark olup olmadığının tespit edilmesi için geliştirilen ana hipotez ve alt hipotezler aşağıdadır:

$\mathbf{H}_{\mathbf{c}}$. Tüketicilerin sosyo-demografik özellikleri ile ilgilenim boyutları arasında anlamlı bir farklılık vardır. 
$\mathbf{H}_{\mathrm{c} 1}$. Katılımcıların cinsiyetleri ile ilgi ve haz boyutu arasında anlamlı bir farklılık vardır.

$\mathbf{H}_{\mathrm{c} 2}$. Katılımcıların cinsiyetleri ile sembolik değer boyutu arasında anlamlı bir farklılık vardır.

$\mathbf{H}_{\mathrm{c} 3}$. Katılımcıların cinsiyetleri ile hata olasılığı boyutu arasında anlamlı bir farklıık vardır.

$\mathbf{H}_{\mathrm{c} 4}$. Katılımcıların cinsiyetleri ile risk önemi boyutu arasında anlamlı bir farklılık vardır.

$\mathbf{H}_{\mathrm{c} 5}$. Katılımcıların cinsiyetleri ile menşei farkındalığı boyutu arasında anlamlı bir farklılık vardır.

$\mathbf{H}_{\mathbf{c 6}}$. Katılımcıların cinsiyetleri ile ürün bilgisi boyutu arasında anlamlı bir farklılık vardır.

$\mathbf{H}_{c 7}$. Katılımcıların cinsiyetleri ile ürün özellikleri bilinci arasında anlamlı bir farklıık vardır.

Tüm faktörler için bağımsız örnek t-testi uygulanmıştır. Yapılan t-testi sonuçlarına göre, 0,05 anlamlılık düzeyinde faktör 3 için 0,001; faktör 5 için 0,011 ve faktör 7 için 0,039 olduğundan, belirtilen bu faktörler için cinsiyet grupları arasında anlamlı bir farklılık tespit edilmiştir. Yani, $\mathrm{H}_{\mathrm{c} 3}, \mathrm{H}_{\mathrm{c5}}$ ve $\mathrm{H}_{\mathrm{c} 7}$ hipotezleri kabul edilmiştir. Ancak diğer faktörlerin $\mathrm{p}$ değerleri $0,05^{\prime \prime}$ ten büyük olduğundan cinsiyet grupları arasında istatistiksel olarak anlamlı bir farklılık yoktur. Yani, $H_{c 1}, H_{c 2}, H_{c 4}$ ve $H_{c 6}$ hipotezleri rededilmiştir.

Tablo 12: Katılımcıların Medeni Durumları İle İgilenim Boyutları Arasındaki Farklılığının Tespitine Yönelik Bağımsız Örnekler İçin T-Testi Tablosu

\begin{tabular}{|c|c|c|c|c|c|}
\hline & $\begin{array}{c}\text { Bekar } \\
(\mathrm{N}=\mathbf{2 4 0})\end{array}$ & Evli $(N=160)$ & $\mathbf{t}$ & df & Sig. \\
\hline F1: İlgi ve Haz & 3,2931 & 3,0750 & 2,434 & 375,581 & 0,015 \\
\hline F2: Sembolik Değer & 2,4972 & 2,4000 & 0,924 & 398 & 0,356 \\
\hline F3: Hata Olasılığı & 2,6889 & 2,7167 & $-0,310$ & 398 & 0,756 \\
\hline F4: Risk Önemi & 3,5028 & 3,4250 & 0,913 & 398 & 0,362 \\
\hline F5: Ürün Menşei Farkındalığı & 3,0771 & 3,2281 & $-1,537$ & 398 & 0,125 \\
\hline F6: Ürün Bilgisi & 3,7717 & 3,3575 & 5,425 & 398 & 0,000 \\
\hline F7: Ürün Özellikleri Bilinci & 3,7639 & 3,7208 & 0,499 & 398 & 0,618 \\
\hline
\end{tabular}

Faktör analizi sonucunda elde edilen yedi faktöre ait ortalamalarda bekar katılımcılar ile evli katılımcıların arasında anlamlı bir fark olup olmadığının tespit edilmesi için geliştirilen alt hipotezler:

$\mathbf{H}_{\text {md1 }}$. Katılımcıların medeni durumları ile ilgi ve haz boyutu arasında anlamlı bir farklılık vardır.

$\mathbf{H}_{\text {md2 }}$. Katılımcıların medeni durumları ile sembolik değer boyutu arasında anlamlı bir farklıık vardır.

$\mathbf{H}_{\text {md3 }}$. Katılımcıların medeni durumları ile hata olasılığı boyutu arasında anlamlı bir farklııı vardır.

$\mathbf{H}_{\text {md4. }}$ Katılımcıların medeni durumları ile risk önemi boyutu arasında anlamlı bir farklılık vardır.

$\mathbf{H}_{\text {md5 }}$. Katılımcıların medeni durumları ile menşei farkındalığı boyutu arasında anlamlı bir farklııık vardır.

$\mathbf{H}_{\text {md6 }}$. Katılımcıların medeni durumları ile ürün bilgisi boyutu arasında anlamlı bir farklılık vardır.

$\mathbf{H}_{\text {md7 }}$ Katılımcıların medeni durumları ile ürün özellikleri bilinci arasında anlamlı bir farklıık vardır.

Faktörlerin tümü için bağımsız örnek t-testi uygulanan çalışma sonunda, 0,05 anlamlılık düzeyinde faktör 1 için 0,015 ve faktör 6 için 0,000 olduğundan, belirtilen bu faktörler için medeni durumları arasında anlamlı bir farklılık tespit edilmiştir. Yani, $H_{m d 1}$ ve $H_{m d \sigma}$ hipotezleri kabul edilmiştir. Ancak diğer faktörlerin, $p$ değerlerinin 0,05 anlamlılık düzeyinin üzerinde çıkması, bu faktörler açısından medeni durumları arasında istatistiksel olarak anlamlı bir farklılık olmaması anlamına gelmektedir. Yani, $\mathrm{H}_{\mathrm{md} 2}, \mathrm{H}_{\mathrm{md} 3}, \mathrm{H}_{\mathrm{md4}}, \mathrm{H}_{\mathrm{md5}}$ ve $\mathrm{H}_{\mathrm{md} 7}$ hipotezleri rededilmiştir.

Bu çalışmada uygulanan tek yönlü varyans analizi sonuçları yorumlanırken varyansların homojenliği durumlarının tespiti için Levene Testi sonuçları da yorumlanmıştır. Ayrıca, homojen dağılmayan varyansların bulunduğu faktörlerde görülen farklılı̆ın tespiti için $f$ değerini daha gerçeğe yakın hesaplamaya yarayan Tamhane's $T 2$ testi uygulanmıştır. Homojen dağıldığı tespit edilen varyansların ait oldukları faktörlerde, tek yönlü varyans analizi sonucu farklıık görülen $(p<0,05)$ ifadeler için gözlenen bu farklılı̆ın tespiti Tukey testi ile yorumlanmıştır. Araştırmaya katılan tüketicilerin sosyo-demografik faktörler ile ilgilenim boyutları ortalamaları arasındaki farklıığın tespitine yönelik yapılan anova testi sonuçları Tablo-13'te verilmiştir. 
Tablo 13: Katılımcıların Sosyo-Demografik İle İlgilenim Boyutları Arasındaki Tek Yönlü Anova Testi

\begin{tabular}{|c|c|c|c|c|c|c|c|c|}
\hline & \multicolumn{2}{|c|}{ Yaş } & \multicolumn{2}{|c|}{ Aylık Kişisel Gelir } & \multicolumn{2}{|c|}{ Eğitim } & \multicolumn{2}{|c|}{ Meslek } \\
\hline & $\mathbf{F}$ & sig & $\mathbf{F}$ & sig & $\mathbf{F}$ & sig & $\mathbf{F}$ & sig \\
\hline F1: İlgi ve Haz & 1,345 & 0,252 & 3,335 & 0,003 & 0,529 & 0,714 & 0,175 & 0,913 \\
\hline F2: Sembolik Değer & 4,329 & 0,002 & 3,111 & 0,005 & 9,586 & 0,000 & 1,281 & 0,280 \\
\hline F3: Hata Olasılığı & 2,358 & 0,105 & 3,732 & 0,001 & 0,790 & 0,532 & 5,342 & 0,001 \\
\hline F4: Risk Önemi & 2,408 & 0,049 & 5,224 & 0,000 & 2,682 & 0,031 & 4,053 & 0,007 \\
\hline F5: Ürün Menşei Farkındalığı & 1,487 & 0,225 & 2,220 & 0,040 & 0,476 & 0,754 & 0,870 & 0,457 \\
\hline F6: Ürün Bilgisi & 5,740 & 0,000 & 1,514 & 0,172 & 2,169 & 0,072 & 4,457 & 0,004 \\
\hline F7: Ürün Özellikleri Bilinci & 4,808 & 0,001 & 2,563 & 0,019 & 2,350 & 0,054 & 1,124 & 0,339 \\
\hline
\end{tabular}

Faktör analizi sonucunda elde edilen yedi faktöre ait ortalamalarda katılımcıların sosyo-demografik ile ilgilenim boyutları arasında anlamlı bir fark olup olmadığının tespit edilmesi amaçlanmıştır. Bu doğrultuda hipotezler geliştirilmiştir.

$\mathbf{H}_{\mathbf{y} 1}$. Katılımcıların yaşları ile haz ve ilgi boyutu arasında anlamlı bir farklılık vardır.

$\mathbf{H}_{\mathbf{y 2}}$. Katılımcıların yaşları ile sembolik değer boyutu arasında anlamlı bir farklılık vardır.

$\mathbf{H}_{\mathbf{y} 3}$. Katılımcıların yaşları ile hata olasılığı boyutu arasında anlamlı bir farklııı vardır.

$\mathbf{H}_{\mathrm{y} 4}$. Katılımcıların yaşları ile risk önemi boyutu arasında anlamlı bir farklılık vardır.

$\mathbf{H}_{\mathrm{y} 5}$. Katılımcıların yaşları ile ürün menşei farkındalığı boyutu arasında anlamlı bir farklılık vardır.

$\mathbf{H}_{\mathbf{y 6}}$. Katılımcıların yaşları ile ürün bilgisi boyutu arasında anlamlı bir farklılık vardır.

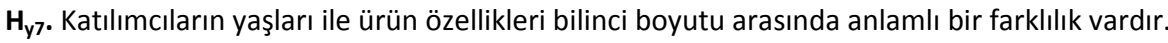

Yapılan anova testi sonucunda, faktör 2, faktör 3 ve faktör 5 grup varyanslarının homojen olmadığı tespit edilmiştir. Yapılan bu tüm testlerin sonuçlarına göre, 0,05 anlamlılık seviyesinde faktör 2, faktör 4, faktör 6 ve faktör 7 ile tüketicinin yaşları arasında anlamlı bir fark bulunurken, diğer faktör ile yaş grupları arasında anlamlı bir fark bulunmamıştır. Sonuç olarak, $\mathrm{H}_{\mathrm{y} 2}$, $\mathrm{H}_{\mathrm{y} 4}, \mathrm{H}_{\mathrm{y} 6}$, ve $\mathrm{H}_{\mathrm{y} 7}$ hipotezleri kabul edilmiştir. Yaş grupları açısından geliştirilen diğer hipotezler ise reddedilmiştir.

$\mathbf{H}_{\text {akg1}}$. Katılımcıların aylık kişisel gelir seviyesi ile haz ve ilgi boyutu arasında anlamlı bir farklılık vardır.

$\mathbf{H}_{\text {akg2. }}$ Katılımcıların aylık kişisel gelir seviyesi ile sembolik değer boyutu arasında anlamlı bir farklılık vardır.

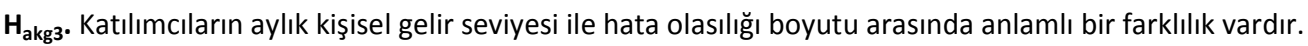

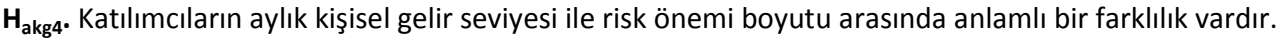

$\mathbf{H}_{\text {akg5. }}$ Katılımcıların aylık kişisel gelir seviyesi ile ürün menşei farkındalığı boyutu arasında anlamlı bir farkııık vardır.

$\mathbf{H}_{\text {akg6. }}$ Katılımcıların aylık kişisel gelir seviyesi ile ürün bilgisi boyutu arasında anlamlı bir farklılık vardır.

$\mathbf{H}_{\text {akg7. }}$ Katılımcıların aylık kişisel gelir seviyesi ile ürün özellikleri bilinci boyutu arasında anlamlı bir farklılık vardır.

Yapılan anova testi sonucunda, faktör 3, faktör 4, faktör 6 ve faktör 7 grup varyanslarının homojen olmadığı tespit edilmiştir. Yapılan bu tüm testlerin sonuçlarına göre, 0,05 anlamlılık seviyesinde faktör 1, faktör 2, faktör 3, faktör 4, faktör 5 ve faktör 7 ile tüketicinin aylık kişisel gelir seviyesi arasında anlamlı bir fark bulunurken, diğer faktör ile aylık kişisel gelir seviyesi grupları arasında anlamlı bir fark bulunmamıştır. Sonuç olarak, $\mathrm{H}_{\mathrm{akg} 1}, \mathrm{H}_{\mathrm{akg} 2}, \mathrm{H}_{\mathrm{akg} 3}, \mathrm{H}_{\mathrm{akg} 4}, \mathrm{H}_{\mathrm{akg} 5}$ ve $\mathrm{H}_{\mathrm{akg}}$ hipotezleri kabul edilmiştir. Aylık kişisel gelir seviyesi grupları açısından geliştirilen diğer hipotezler ise reddedilmiştir.

$\mathbf{H}_{\text {ed1 }}$. Katılımcıların eğitim durumları ile haz ve ilgi boyutu arasında anlamlı bir farklılık vardır.

$\mathbf{H}_{\text {ed2}}$. Katılımcıların eğitim durumları ile sembolik değer boyutu arasında anlamlı bir farklılık vardır.

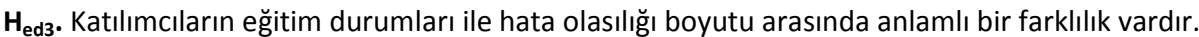

$\mathbf{H}_{\text {ed4. }}$ Katılımcıların eğitim durumları ile risk önemi boyutu arasında anlamlı bir farklılık vardır.

$H_{\text {ed5. }}$ Katııımcıların eğitim durumları ile ürün menşei farkındalığı boyutu arasında anlamlı bir farklııı vardır.

$\mathbf{H}_{\text {ed6}}$. Katılımcıların eğitim durumları ile ürün bilgisi boyutu arasında anlamlı bir farklıık vardır. 
$\mathbf{H}_{\text {ed7 }}$. Katılımcıların eğitim durumları ile ürün özellikleri bilinci boyutu arasında anlamlı bir farklılık vardır.

Tablo 13'de görüldüğü gibi, eğitim durumları faktörünün varyans analizinin ön şartını sağladığı tespit edilmiş, yalnızca homojen olmayan faktör 2'ye Anova testinin alternatifi olan Tamhane's T2 uygulanmıştır. Yapılan bu tüm testlerin sonuçlarına göre, 0,05 anlamlılık seviyesinde faktör 2 ve faktör 4 ile tüketicinin kullandığı cep telefonunu markası grupları arasında anlamlı bir fark bulunurken, diğer faktörler ile arasında anlamlı bir fark bulunmamıştır. Sonuç olarak, $\mathrm{H}_{\mathrm{ed2}}$ ve $\mathrm{H}_{\mathrm{ed} 4}$ hipotezleri kabul edilmiştir. Kullanııının eğitim durumu grupları açısından geliştirilen diğer hipotezler ise reddedilmiştir.

$\mathbf{H}_{\mathbf{m} 1}$. Katılımcıların meslekleri ile haz ve ilgi boyutu arasında anlamlı bir farklılık vardır.

$\mathbf{H}_{\mathbf{m} 2}$. Katılımcıların meslekleri ile sembolik değer boyutu arasında anlamlı bir farklııı vardır.

$\mathbf{H}_{\mathbf{m} 3}$. Katılımcıların meslekleri ile hata olasılığı boyutu arasında anlamlı bir farklılık vardır.

$\mathbf{H}_{\mathbf{m} 4}$. Katılımcıların meslekleri ile risk önemi boyutu arasında anlamlı bir farklılık vardır.

$\mathbf{H}_{\mathrm{m} 5}$. Katılımcıların meslekleri ile ürün menşei farkındalığı boyutu arasında anlamlı bir farklılık vardır.

$\mathbf{H}_{\mathbf{m 6}}$. Katılımcıların meslekleri ile ürün bilgisi boyutu arasında anlamlı bir farklılık vardır.

$\mathbf{H}_{m 7}$. Katılımcıların meslekleri ile ürün özellikleri bilinci boyutu arasında anlamlı bir farklılık vardır.

Yapılan anova testi sonucunda, faktör 1, faktör 3, faktör 4 ve faktör 5 grup varyanslarının homojen olmadığı tespit edilmiştir. Yapılan bu tüm testlerin sonuçlarına göre, 0,05 anlamlılık seviyesinde faktör 3, faktör 4 ve faktör 6 ile tüketicinin meslek grupları arasında anlamlı bir fark bulunurken, diğer faktörler ile meslek grupları arasında anlamlı bir fark bulunmamıştır. Sonuç olarak, $\mathrm{H}_{m 3}, \mathrm{H}_{\mathrm{m} 4}$ ve $\mathrm{H}_{\mathrm{m} 6}$ için geliştirilen hipotezler kabul edilmiştir. Meslek grupları açısından geliştirilen diğer hipotezler ise reddedilmiştir.

Sosyo-demografik özelliklerden cep telefonu temin etme şekilleri incelendiğinde, alışveriş merkezlerinden temin eden kişi sayısı 250, hediye edildiğini belirten 52 kişi, cep telefonun ikinci el olduğunu belirten 18 kişi, İnternet'ten sipariş verdiğini söyleyen kişi sayısı 16 ve diğer seçeneğini işaretleyen kişi sayısı 64'dür. Bu nedenle, anlamlı bir karşılaştırma yapılamayacağı düşünülmüş ve farklılık testi yapılmamıştır.

Çalışmada, çoklu doğrusal regresyon analizi ile katılımcıların ilgilenim faktörlerinin marka sadakatine etkisi incelenmiştir. Üzerinde çalışılan modelin genel olarak anlamlı olduğu tespit edilmiştir ( $F=51,333 ; P=0,000)$. Tablo 14'de görüldüğü gibi, oluşan regresyon modelinde bağımlı değişkenin bağımsız değişkenler ile ilişkisinin 0,692 olduğu, bağımsız değişkenlerin bağımlı değişken üzerindeki değişimin ise \% 46,9'unu açıklayabildiği görülmektedir ( $R=0,692 ; R$ square=0,478).

Tablo 14: Regresyon Modeli Özeti

\begin{tabular}{ccccc}
\hline Model & $\mathbf{R}$ & $\mathbf{R}^{\mathbf{2}}$ & Düzeltilmiş $\mathbf{R}^{\mathbf{2}}$ & Standart Hata Oranı \\
\hline 1 & 0,692 & 0,478 & 0,469 & 0,60539 \\
\hline
\end{tabular}

Tablo 15'e göre regresyon modelinin anlamlıık seviyesi 0,000'dır. Böylece modelin anlamlı olduğu, bağımlı değişkeninin bağımsız değişkenlerle tahmin edilmesinin istatistiksel olarak mümkün olduğu anlaşılmaktadır.

Tablo 15: Regresyon Analizi Anova Tablosu

\begin{tabular}{ccccccc}
\hline Model & & Karelerin Toplamı & df & Ortalama-Kare & F & Sig. \\
\hline \multirow{2}{*}{1} & Regresyon & 131,692 & 7 & 18,813 & 51,333 \\
& Kalıntı Toplam & 143,665 & 392 & 0,366 & \\
& & 275,356 & 399 & & \\
\hline
\end{tabular}

Tablo 16 'da, marka sadakatine etki eden faktörlere ait regresyon katsayıları verilmiştir. Bağımsız değişkenler arasında çoklu bağıntı olup olmadığını sınamak amacıyla çoklu bağıntı analizi yapılmıştır. 
Tablo 16: Regresyon Analizi Sonucu

\begin{tabular}{|c|c|c|c|c|c|c|}
\hline & & $\begin{array}{c}\text { Standardize } \\
\text { Olmayan } \\
\text { Katsayılar }\end{array}$ & $\begin{array}{c}\text { Standardize } \\
\text { Olmuş } \\
\text { Katsayılar }\end{array}$ & $\mathbf{t}$ & Sig. & VIF Değeri \\
\hline Model & & B & Beta & & & \\
\hline \multirow[t]{8}{*}{1} & (Sabit) & 0,208 & & 0,882 & 0,378 & \\
\hline & F1: İlgi ve Haz & & 0,141 & 3,241 & 0,001 & 1,425 \\
\hline & F2: Sembolik Değer & & 0,093 & 2,347 & 0,019 & 1,172 \\
\hline & F3: Hata Olasılığı & & $-0,057$ & $-1,371$ & 0,171 & 1,297 \\
\hline & F4: Risk Önemi & & 0,120 & 2,823 & 0,005 & 1,347 \\
\hline & F5: Ürün Menşei Farkındalığı & & 0,043 & 1,127 & 0,260 & 1,100 \\
\hline & F6: Ürün Bilgisi & & 0,118 & 2,597 & 0,010 & 1,541 \\
\hline & F7: Ürün Özellikleri Bilinci & & 0,504 & 12,725 & 0,000 & 1,180 \\
\hline
\end{tabular}

Tablo 16'da da görüldüğü gibi, regresyon analizi sonucunda marka sadakatine istatistiksel olarak anlamlı etki eden faktörler, standardize olmuş Beta katsayıları dikkate alınarak, aşağıdaki gibi ifade edilebilir: Marka sadakati $=0,208+0,504$ (ürün özellikleri bilinci)

Marka sadakati $=0,208+0,141$ (ilgi ve haz)

Marka sadakati $=0,208+0,120$ (risk önemi)

Marka sadakati $=0,208+0,118$ (ürün bilgisi)

Marka sadakati $=0,208+0,093$ (sembolik değer)

Regresyon analizi sonucundan da anlaşılacağı gibi, marka sadakatini en fazla etkileyen faktörler sırasıyla "ürün özellikleri bilinci", "ilgi ve haz", "risk önemi", "ürün bilgisi" ve "sembolik değer"dir.

\section{SONUÇ}

Katılımcıların demografik durumları ile ilgilenim faktörlerine yönelik analizlerde cinsiyet ile ilgilenim faktörlerine yönelik tutumları incelendiğinde, erkek katılımcılar kadın katılımcılara nazaran cep telefonu satın aldıktan sonra daha yüksek oranda kararsızık yaşamakta ve hata yaptıklarını düşünmektedirler. Ayrıca erkekler, cep telefonunun menşeine, kadınlardan daha fazla önem vermekte ve kadınlardan daha fazla menşei ile kalitesi arasında ilişki olduğunu düşünmektedir. Bunun yanı sıra, kadınlar, erkeklere göre cep telefonu özelliklerine karşı daha fazla bilinçli olduğu tespit edilmiştir. Katılımcıların medeni durumları ile ilgilenim faktörlerine yönelik tutumları incelendiğinde, medeni durumu bekar olan kişiler cep telefonuna daha fazla ilgi duymakta ve bunlar için bir cep telefonuna sahip olmak evli kişilere göre kendilerine daha çok haz ve mutluluk vermektedir. Katılımcıların demografik özellikleri ile cep telefonu satın alımlarında "marka" unsurunu bir tercih sebebi olarak görüp görmedikleri ile incelendiğinde; her yaş grubunun cep telefonu markasına önem verdiği sonucuna ulaşılmıştır. Araştırmaya katılan 18-25 yaş grubu genç katılımcılar markaya en fazla önem veren gruptur. Medeni durumlar incelendiğinde, bekar katılımcılar evli katılımcılara göre markaya daha çok önem vermektedir. Aylık kişisel gelir baz alınarak incelendiğinde, katılımcılar maddiyatı göz önüne almaksızın cep telefonu alırken markaya dikkat etmektedirler.

Tüm katılımcıların, toplamda \%73,5'inin telefonlarını iki yıldan uzun bir süredir kullanmıyor olmaları, cep telefonlarını sıklıkla değiştirdiklerinin bir göstergesi olabilir. Araştırmamıza katılanların \%84'ü beklenildiği gibi marka unsurunun kendileri için önemli olduğnu belirtmişlerdir. Ancak, \%16"sı cep telefonu satın alımlarında "marka" unsurunun kendileri için önemli bir kriter olmadığını belirtmiştir. Bu \%16'lık tüketici kesimi cep telefonlarını değiştirmek istediklerinde herhangi bir markayı tercih edebileceklerdir. Özellikle Apple markasını kullanan katılımcıların \%78,2'si kullandıkları cep telefonunu iki yıldan daha fazla kullanmadıkları tespit edilmiştir. Yaş gruplarına bağlı olarak, sembolik değer, risk önemi, ürün bilgisi ve ürün menşei farkındalığı faktörlerinde farklılıklar bulunduğu ortaya çıkmıştır. Sembolik değer faktöründe 26-33 yaş grubunda bulunanlar ile 34-41 yaş grubunda bulunanlar arasında anlamlı bir farklılık çıkmıştır. Risk önemi faktöründe, yaş grupları arasında anlamlı bir farklılık bulunamamıştır. Ürün bilgisi faktöründe 18-25 yaş grubunda bulunanlar ile 26-33 yaş, 34-41 yaş, 50-50 yaş üzeri grubunda bulunanlar arasında anlamlı farklılık çıkmıştır. Ürün özellikleri bilinci faktöründe 18-25 yaş grubunda bulunanlar ile 50-50 yaş üzeri grubunda bulunanlar arasında anlamlı farklılık çıkmıştır.

Çalışmada çoklu doğrusal regresyon analizi ile katılımcıların ilgilenim faktörleri ile marka sadakatlerine olan etkisi incelenmiştir. Araştırmaya katılan tüketicilerin marka sadakatine en yüksek etki eden faktörün ürün özellikleri bilinci olduğu sonucuna varılmıştır. Tüm ilgilenim faktörleri marka sadakatinin $\% 46,69^{\prime}$ unu açıklamaktadır $\left(R^{2}=0,469\right)$ Sırasıyla ilgi ve haz, 
risk önemi, ürün bilgisi ve sembolik değer marka sadakatinde etkili olan diğer faktörlerdir. Tüketicilerin ürün özellikleri bilincinin yüksek olması markaya duyulan sadakatinde artmasına sebep olmaktadır. Daha açıkca belirtmek gerekirse, tüketicilerin kullandıkları cep telefonlarının özelliklerinin düzgün çalışıyor olması, cep telefonlarının çok sık bakıma gerek duymaması ve ihtiyaçlarını karşılıyor olması marka sadakati oluşturmada önemli durumlardır. Bu faktör, bir cep telefonu üreticisi tüketicilerin sadakatini korumak istiyorsa, ürünlerin kalitesine odaklanmak zorunda olduğunu gösteriyor. Böylelikle, tüketiciler cep telefonlarının markasını takdir edecekler ve sonuçta markaya sadık kalacaklardır. ilgi ve haz faktörünün marka sadakati üzerinde pozitif etkisinin olması, tüketicilerin cep telefonuna duyduğu ilgi ve haz seviyesini artırmanın markaya karşı sadakati artıracağı sonucunu ortaya çıkarmaktadır. Araştırmamıza benzer bir çalışmada Hanzaee vd., (2011), cep telefonu kullanan öğrenciler üzerinde yapmış olduğu çalışmada, haz boyutunun marka sadakati üzerinde doğrudan bir etkisi olduğunu tespit etmiştir. Risk önemi boyutu incelendiğinde, tüketicilerin duyduğu riskin marka sadakatini etkilediği analizler sonucunda tespit edilmiştir. Ürün bilgisinin marka sadakati üzerinde pozitif etkisinin olması, cep telefonu üreten firmaların tüketicilerin ürün hakkında daha çok bilgilendirilmesi için daha fazla çaba sarf etmeleri gerektiğini ortaya çıkartmaktadır. Tüketiciler bir marka hakkında ne kadar çok bilgiye sahip ise o markaya karşı bir o kadar sadık kalacaklardır. Son olarak, sembolik değerin marka sadakati üzerinde pozitif etkisinin olması, kişinin kullandığı cep telefonuna bakarak onun hakkında fikir vermesini ifade etmesi ile açıklanabilir. Cep telefonu firmalarının tüketicilerin bu gereksinimini karşılaması gerekmektedir. Bu çalışma, Douglas (2006)'nın yapmış olduğu çalışmayla benzerlik göstermektedir.

Marka sadakatine etkisi olmayan faktörlerin ise hata olasılığı ve ürün menşei farkındalığı olduğu tespit edilmiştir. Tüketicilerin kullanmakta oldukları cep telefonunun menşei ile kalitesi arasında bir ilişkinin olmadığı ve hangi ülkede üretildiğinin (menşei) öneminin marka sadakati üzerinde herhangi bir etkisinin olmadığı sonucuna varılmıştır. Ayrıca, hata olasılığı kapsamında incelenen katılımcıların cep telefonu satın aldıklarında doğru bir seçim yapıp yapmadıklarına emin olamamasının marka sadakatine etkisi olmadığı tespit edilmiştir. Bu çalışma, Douglas (2006)'nın hata olasılı̆ııın marka sadakati üzerinde pozitif etkisi olduğunu bulduğu çalışmasıyla paralellik göstermemektedir.

\section{KAYNAKLAR}

Aaker, D.A., (1991). Managing brand equity, Free Press, New York, NY.

Antil, J. H., (1984). Conceptualization and operationalization of involvement. Advances in Consumer Research, 11, $203-209$.

Babin, B. J., Darden, W. R., and Griffin, M. (1994). Work and/or fun: measuring hedonic and utilitarian shopping value. Journal of Consumer Research, 20(4), 644-656.

Batra, R., and Ahtola, O. T. (1991). Measuring the hedonic and utilitarian sources of consumer attitudes. Marketing Letters, 2(2), $159-170$.

Bellenger, D. N., Steinberg, E., and Stanton, W. W. (1976). Congruence of store image and self image-as it relates to store loyalty. Journal of Retailing, 52(1), 17-32.

Biong, H., (1993). Satisfaction and loyalty to suppliers within the grocery trade. European Journal of Marketing, 27(7), 21-38.

Bloemer, J. M., and Kasper, H. D. (1995). The complex relationship between consumer satisfaction and brand loyalty. Journal of Economic Psychology, 16(2), 311-329.

Brucks, M., (1985). The effects of product class knowledge on information search behavior. Journal of Consumer Research, 12(1), 1-16.

Chao, P., and Rajendran, K. N. (1993). Consumer profiles and perceptions: country-of-origin effects. International Marketing Review, 10(2), 22-39.

Dekimpe, M. G., Steenkamp, J. B. E., Mellens, M., and Abeele, P. V. (1997). Decline and variability in brand loyalty. International Journal of Research in Marketing, 14(5), 405-420.

Elliott, R., and Hamilton, E. (1991). Consumer choice tactics and leisure activities. International Journal of Advertising, 10(4), 325-332.

Friedman, M. L., and Smith, L. J. (1993). Consumer evaluation processes in a service letting. Journal of Services Marketing, 7(2), 47-61.

Guthrie, M. F., and Kim, H. S. (2009). The relationship between consumer involvement and brand perceptions of female cosmetic consumers. Journal of Brand Management, 17(2), 114-133.

Hirschman, E. C., and Holbrook, M. B. (1982). Hedonic consumption: emerging concepts, methods and propositions. The Journal of Marketing, 46, 92-101.

https://www.ama.org/resources/pages/dictionary.aspx?dLetter=B, Erişim Tarihi: Nisan-2017

http://www.idc.com/promo/smartphone-market-share/vendor, Erişim Tarihi: Nisan-2017 
Hupfer, N. T. and Gardner D. M. (1971), Differential involvement with products and issues: an exploratory study. In Proceedings of the Association for Consumer Research, 2nd Conference, D. M. Gardner, ed. College Park, MD, 262-269.

Jacoby, Jacob and David B. Kyner. 1973. Brand loyalty vs. repeat purchase behavior. Journal of Marketing Research, 10, 1-9.

Josiam, B. M., Kinley, T. R., and Kim, Y. K. (2005). Involvement and the tourist shopper: Using the involvement construct to segment the american tourist shopper at the mall. Journal of Vacation Marketing, 11(2), 135-154.

Iwasaki, Y., and Havitz, M. E. (1998). A path analytic model of the relationships between involvement. Psychological Commitment, and Loyalty. Journal of Leisure Research, 30(2), 256-280

Kapferer, J. N., and Laurent, G. (1993). Further evidence on the consumer involvement profile: five antecedents of involvement. Psychology \& Marketing, 10(4), 347-355.

Leclerc, F., and Little, J. D. (1997). Can advertising copy make FSI coupons more effective?. Journal of Marketing Research, 34, $473-484$.

Lee, J. K., and Lee, W. N. (2009). Country-of-origin effects on consumer product evaluation and purchase intention: the role of objective versus subjective knowledge. Journal of International Consumer Marketing, 21(2), 137-151.

Liang, C. J., and Wang, W. H. (2008). Do loyal and more involved customers reciprocate retailer's relationship efforts?. Journal of Services Research, 8(1), 63-90.

Lin, L. Y., and Chen, C. S. (2006). The influence of the country-of-origin image, product knowledge and product involvement on consumer purchase decisions: an empirical study of insurance and catering services in taiwan. Journal of Consumer Marketing, 23(5), 248-265.

Lin, L. Y., and Zhen, J. H. (2005). Extrinsic product performance signaling, product knowledge and customer satisfaction: an integrated analysis-an example of notebook consumer behavior in taipei city. Fu Jen Management Review, 12(1), 65-91.

Maclnnis, D. J., and Price, L. L. (1987). The role of imagery in information processing: review and extensions. Journal of Consumer Research, 13(4), 473-491.

Michaelidou, N., and Dibb, S. (2008). Consumer involvement: a new perspective. The Marketing Review, 8(1), 83-99.

Mittal, B., and Lee, M. (1988). Separating brand-choice involvement from product involvement via consumer involvement profiles. Advances in Consumer Research, 15, 43-49.

Mittal, B., and Lee, M. S. (1989). A causal model of consumer involvement. Journal of Economic Psychology, 10(3), 363-389.

Morris, J. D., Woo, C., Geason, J. A., and Kim, J. (2002). The power of affect: predicting intention. Journal of Advertising Research, 42(3), 717.

Nguyen Duc, D., (2013). Impact of product involvement factors on cell phone users' loyalty in Ho Chi Minh City (Doctoral dissertation, International University HCMC, Vietnam).

Oliver, L. Richard.. (1997). Satisfaction: a behavioral perspective on the consumer. New York: McGraw-Hill.

Oliver, R. L. (1999). “Whence Consumer Loyalty?”, The Journal of Marketing, 64, 33-44.

Overby, J. W., and Lee, E. J. (2006). The effects of utilitarian and hedonic online shopping value on consumer preference and intentions. Journal of Business Research, 59(10), 1160-1166.

Quester, P., and Lim L. A. (2003). Product involvement/brand loyalty: is there a link?. Journal of Product and Brand Management, 12(1), 2238.

Petty, R. E., Cacioppo, J. T., and Schumann, D. (1983). Central and peripheral routes to advertising effectiveness: the moderating role of involvement. Journal of consumer research, 10(2), 135-146.

Richins, M. L., and Bloch, P. H. (1986). After the new wears off: the temporal context of product involvement. Journal of Consumer Research, 13(2), 280-285

Rodgers, W. C., and Schneider, K. C. (1993). An empirical evaluation of the Kapferer-Laurent consumer involvement profile scale. Psychology \& Marketing, 10(4), 333-345.

Roth, M. S., and Romeo, J. B. (1992). Matching product categeory and country image perceptions: a framework for managing country-oforigin effects. Journal of international Business Studies, 23(3), 477-497.

Rundle-Thiele, S., and Maio Mackay, M. (2001). Assessing the performance of brand loyalty measures. Journal of Services Marketing, 15(7), 529-546.

Rundle-Thiele, S., (2005). Exploring loyal qualities: assessing survey-based loyalty measures. Journal of Services Marketing, 19(7), 492-500. 
Samiee, S., (1994). Customer evaluation of products in a global market. Journal of International Business Studies, 25(3), 579-604.

Suh, J. C., and Youjae, Y. (2006). When brand attitudes affect the customer satisfaction-loyalty relation: the moderating role of product involvement. Journal of Consumer Psychology, 16(2), 145-155.

Traylor, Mark B., (1981), Product involvement and brand commilment. Journal of Advertising, 21, 51-56.

Xue, F., (2008). The moderating effects of product involvement on situational brand choice. Journal of Consumer Marketing, 25(2), 85-94.

Warrington, P., and Shim, S. (2000). An empirical investigation of the relationship between product involvement and brand commitment", Psychology and Marketing, 17(9), 761-782.

Wirtz, J., and Lee, M. C. (2003). An examination of the quality and context-specific applicability of commonly used customer satisfaction measures. Journal of Service Research, 5(4), 345-355.

Zaichkowsky, J. L. (1985). Measuring the involvement construct. Journal of Consumer Research, 12(3), 341-352. 